\title{
EXTERNAL SOCIETAL COSTS OF ANTIMICROBIAL RESISTANCE IN HUMANS ATTRIBUTABLE TO ANTIMICROBIAL USE IN LIVESTOCK
}

\author{
Gabriel K. Innes \\ Pranay R. Randad \\ Anton Korinek \\ Meghan F. Davis \\ Lance B. Price \\ Anthony D. So \\ Christopher D. Heaney \\ Working Paper 26189 \\ http://www.nber.org/papers/w26189 \\ NATIONAL BUREAU OF ECONOMIC RESEARCH \\ 1050 Massachusetts Avenue \\ Cambridge MA 02138 \\ August 2019
}

This manuscript was prepared for the Annual Review of Public Health. The corresponding authors are Christopher D. Heaney and Anton Korinek. The authors acknowledge Ding Xuan Ng for research assistance and support during the early stages of this project. Funding for this study was provided by the Johns Hopkins University Discovery Award. Gabriel K. Innes was also supported by National Institute of Environmental Health Sciences (NIEHS) grant 5T32ES007141-30. Pranay R. Randad was supported by National Institute for Occupational Safety and Health (NIOSH) Johns Hopkins NIOSH Education and Research Center grant T42OH008428 and a gift from the GRACE Communications Foundation. Anton Korinek was supported by a grant on Macroeconomic Externalities from the Institute for New Economic Thinking. Anthony D. So received support under the Hopkins IDEA (Innovation+Design Enabling Access) Initiative and funding for other projects on antimicrobial resistance from ReAct-Action on Antibiotic Resistance and the Open Society Foundation. Anthony D. So has also served as Co-Convener of the UN Interagency Coordination Group on Antimicrobial Resistance (2018-19), as a member of the Expert Commission on Addressing the Livestock Contribution to the Antibiotic Resistance Crisis (2016-2017), as a commissioned author to the UK Commission on AMR on "A Framework for Costing the Lowering of Antimicrobial Use in Food Animal Production" (2016), as Head of the Secretariat of the Antibiotic Resistance Coalition, and as a Member of the Working Group on Antibiotic Resistance for the President's Council of Advisors on Science and Technology (2013-2014). Meghan F. Davis was supported by the NIH Office of the Director grant K01OD019918. Meghan F. Davis and Christopher D. Heaney were supported by NIAID grant R01AI130066. Chris Heaney was additionally supported by E.W. "Al" Thrasher Award 10287, a gift from the GRACE Communications Foundation, NIEHS grant R01ES026973, and NIAID grants R21AI139784 and R43AI141265. Lance Price is supported by NIAID grant R01AI130066, R01AI123002, R01AI128779 and R01AI125562, alongside the Wellcome Trust award 211493/Z/18/Z. The funders had no role in study design, data analysis, decision to publish, or preparation of the manuscript. The views expressed herein are those of the authors and do not necessarily reflect the views of the National Bureau of Economic Research.

NBER working papers are circulated for discussion and comment purposes. They have not been peerreviewed or been subject to the review by the NBER Board of Directors that accompanies official NBER publications.

(C) 2019 by Gabriel K. Innes, Pranay R. Randad, Anton Korinek, Meghan F. Davis, Lance B. Price, Anthony D. So, and Christopher D. Heaney. All rights reserved. Short sections of text, not to exceed two paragraphs, may be quoted without explicit permission provided that full credit, including $\odot$ notice, is given to the source. 
External Societal Costs of Antimicrobial Resistance in Humans Attributable to Antimicrobial Use in Livestock

Gabriel K. Innes, Pranay R. Randad, Anton Korinek, Meghan F. Davis, Lance B. Price, Anthony D. So, and Christopher D. Heaney

NBER Working Paper No. 26189

August 2019

JEL No. H23,I1,I15,I18,Q18

\section{ABSTRACT}

Antimicrobial use in animal agriculture contributes to antimicrobial resistance in humans, which imposes significant health and economic costs on society. These costs are negative externalities. We review the relevant literature and develop a model to quantify the external costs of antimicrobial use in animal agriculture on antimicrobial resistance in humans. Parameters required for this estimate include: 1) the health and economic burden of antimicrobial resistance in humans, 2) the impact of antimicrobial use in animal agriculture on antimicrobial resistance in animals, 3) the fraction of antimicrobial resistance in humans attributable to animal agriculture, and 4) antimicrobial use in animals. We use a well-documented historic case to estimate an externality cost of about $\$ 1500$ per kilogram of fluoroquinolones administered in US broiler chicken production. Enhanced data collection, particularly on parameters 3) and 4), would be highly useful to quantify more fully the externalities of antimicrobial use in animal agriculture.

Gabriel K. Innes

615 N Wolf Street Room E7527

Bloomberg School of Public Health

Baltimore, MD 21205

United States

ginnes1@jhu.edu

Pranay R. Randad

615 North Wolfe Street

Bloomberg School of Public Health

Baltimore, MD 21205

prandad1@jhmi.edu

Anton Korinek

Department of Economics

University of Virginia

Monroe Hall 246

248 McCormick Rd

Charlottesville, VA 22904

and NBER

anton@korinek.com

Meghan F. Davis

615 N. Wolfe Street E7612

Bloomberg School of Public Health

Baltimore, MD 21205

mdavis65@jhu.edu
Lance B. Price

Milken Institute School of Public Health 950 New Hampshire Ave. NW 4th Floor

Washington, DC 20052

lprice@gwu.edu

Anthony D. So

615 N. Wolfe Street Room E8533

Bloomberg School of Public Health

Baltimore, MD 21205

aso5@jhu.edu

Christopher D. Heaney

615 N. Wolfe Street Room W7033B

Bloomberg School of Public Health

Baltimore, MD 21205

cheaney1@jhu.edu

An XLS Worksheet to calculate externalities is available at http://www.korinek.com/AMR 


\section{Introduction*}

The rising rates of antimicrobial resistance (AMR) in bacterial populations threaten treatment options for these infections globally.(42) The selective pressures created by antimicrobial use (AMU) and misuse in both humans and animals have led to widespread AMR in a broad range of bacteria.(71) Similar to AMU in humans, AMU in animal agriculture can promote AMR in animal and human pathogen populations, which imposes significant health and economic costs on society. $(52,57,71)$ Moreover, these costs are externalities that are not properly reflected in the price of antimicrobials, creating a potential case for public policy intervention.

The focus of this article is to compile the relevant literature and evaluate the pathway through which AMU in animal agriculture contributes to AMR in the human population. We propose a model to estimate the externalities of AMU in animal agriculture. The parameters required to inform this estimate include 1) the health and economic burden of AMR in humans, 2) the impact of AMU in animal agriculture on AMR, 3) the fraction of AMR in humans attributable to animal agriculture, and 4) AMU in animals (Figure 1). We then present a historic case study - the application of the fluoroquinolone antibiotic enrofloxacin to US broiler chickens - and quantify the externalities generated in the form of the additional fluoroquinolone-resistance (FR) of one specific pathogen, Campylobacter spp., in the US in 1999, before the use of fluoroquinolones was banned in the chicken industry. We find an externality cost of $\$ 1500$ per kilogram of enrofloxacin applied. More generally, the estimates produced by our model may inform the policy debate on how to address the growing public health problem of antimicrobial resistance.

\section{Section 1: Total health and economic burden of AMR in humans}

AMR significantly increases the morbidity, mortality, hospital length of stay (LOS), direct healthcare related costs, and indirect societal costs of infections. $(40,73)$ This section reviews the literature on the health and economic impact of AMR in humans. An overview of the studies and reports included in this review are provided in the Supplementary Materials (Table S1 and Sections S1 and S2).

\section{Health impact of AMR}

The United Kingdom (UK) Review on AMR, using studies commissioned by RAND Europe and KPMG, sought to quantify the future health and economic pacts of AMR, worldwide. $(34,58)$ The UK Review on AMR estimated that 700,000 deaths/year are currently attributable to AMR, including malaria, HIV, and tuberculosis.(41) For Enterobacteriaceae, for example, Temkin et al. estimated a total of 6.4 million bloodstream infections (BSIs) and 50.1 million "serious infections" caused by 3rd generation cephalosporin resistant (3GCR)- and carbapenem resistant (CarR)-E. coli and K. pneumoniae worldwide in 2014.(59) However, all available global estimates were hindered by poor surveillance and reporting in Asian and African countries.(37, 41, 59) A World Health Organization (WHO) report also documented that AMR surveillance is neither coordinated nor harmonized, and many gaps exist on bacteria of major public health importance.(69) Global estimates thus require that AMR infection rates for many countries

\footnotetext{
${ }^{*}$ Author Contributions: Gabriel K. Innes and Pranay R. Randad jointly wrote the first draft of the manuscript. Anton Korinek developed the externalities model of section 5. Anthony D. So convened our research group and secured seed funding. Christopher D. Heaney developed the concept of the paper and guided the writing process. All authors reviewed and edited all sections of the paper.
} 


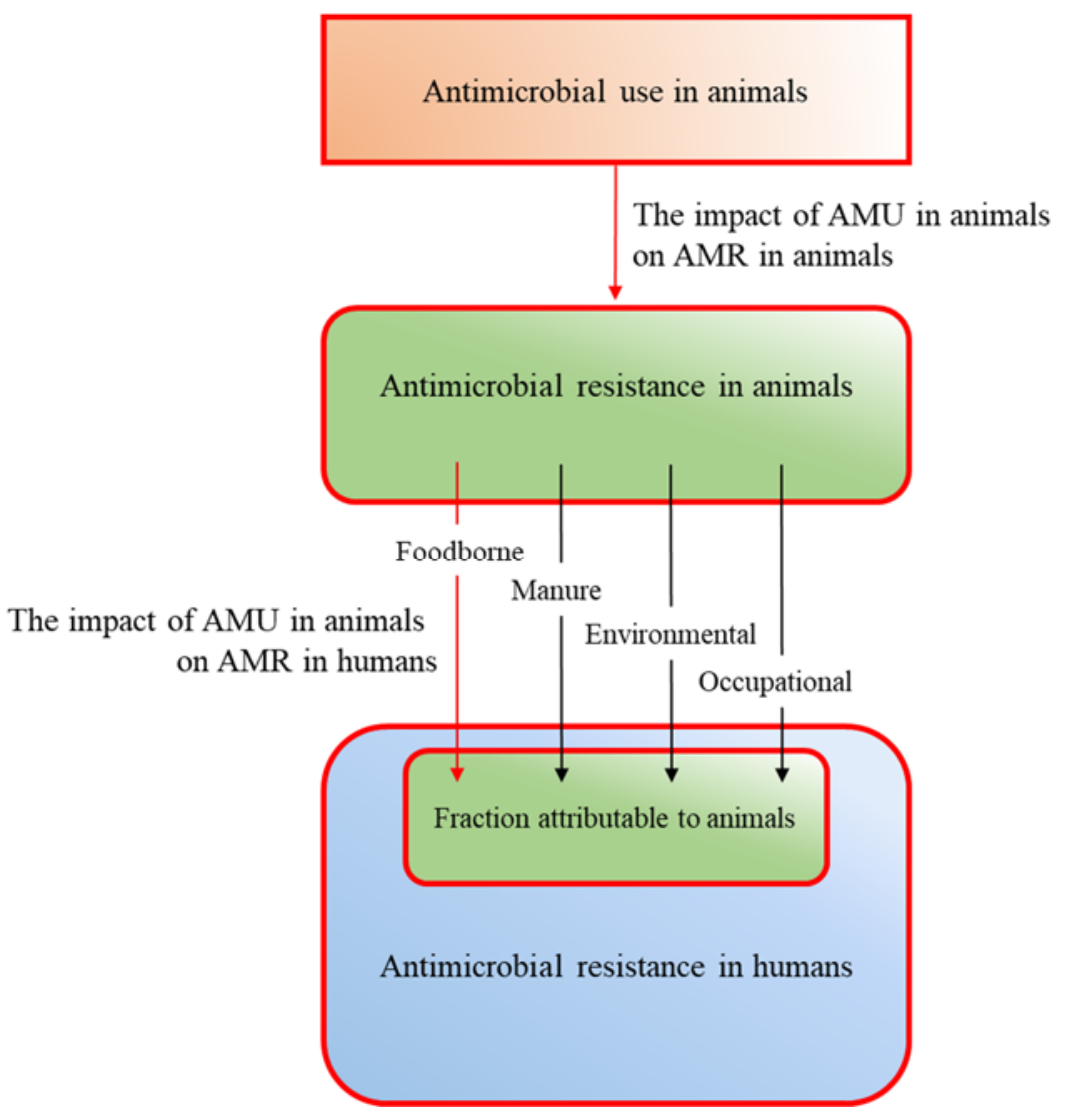

Figure 1: Framework, including parameters required, to estimate the externality cost of antimicrobial resistance (AMR) due to antimicrobial use (AMU) in animal agriculture.

Note. Red lines indicate parameters reviewed and included explicitly in the externalities model. Black lines indicate parameters not covered in the review due to insufficient data to inform externalities estimation. Parameter compartments are not drawn to scale.

are imputed using established AMR surveillance systems, such as the European Antimicrobial Resistance Surveillance Network (EARS-net) data.(41,59)

Higher-quality data allow for more reliable national-level estimates for the US and European Union/European Economic Area (EU/EEA). For the US, Thorpe et al., using US Agency for Healthcare Research and Quality (AHRQ) Medical Expenditure Panel Survey (MEPS) data, estimated an average of 1.2 million AMR infections each year from 2002-2014.(61) During this timeframe, the number of infections remained approximately constant; however, the proportion of infections due to AMR pathogens has more than doubled, from 700,000 to 1.6 million AMR infections.(61) Thorpe et al. did not comment on the attributable mortality due to AMR infections; however, the US Centers for Disease Control and Prevention (CDC) has estimated over 2,000,000 AMR infections and 23,000 deaths annually using 2011 data.(27) A more recent estimate carried out by Washington University in St. Louis investigators place the number of deaths at over 7 times the CDC estimate.(4) For EU/EEA countries, Cassini et al., using EARS-net data, estimated a total of 671,689 cases of AMR infection in 2015, resulting in 33,110 deaths and 874,541 DALYs, from five types of infections with eight different AMR bacteria.(6) Among EU/EEA countries, Italy and Greece had the highest mortality rates from AMR, with about one-third of AMR attributable deaths in all EU/EEA countries occurring in Italy. The study also found that a 
substantial burden of AMR infections in the EU/EEA were attributable to community-associated infections (almost 40\%).(6)

In low and middle-income countries (LMIC), AMR rates are currently high and projected to grow more rapidly than in developed countries.(43) In the Russian Federation, India, and Brazil, 40-60\% of recorded bacterial infections are due to AMR pathogens, compared to an average of $17 \%$ in Organisation for Economic Co-operation and Development (OECD) countries.(43) Data and results provided by the WHO Global Antimicrobial Resistance Surveillance System (WHO GLASS) will be valuable in providing accurate and standardized data to inform estimates on the current and projected health impacts of AMR, especially for LMIC. (70)

\section{Economic Impact of AMR}

Estimates on the economic impact of AMR have adopted two complementary perspectives. A majority of studies have utilized a healthcare/payer perspective: to report excess healthcare-related expenditures associated with the treatment of AMR. $(40,73)$ Several recent reports have incorporated a societal perspective to report the loss of economic output due to AMR.(40,60,73). A summary of the future economic impacts of AMR, based on multiple different projected trends of AMR and infection rates to 2050, is provided in the Supplementary Material. This section of the review focuses on current estimates on the incremental treatment cost of AMR, and the total economic impact of AMR for the USA, including direct healthcare related costs and indirect societal costs.

The current variability in available estimates on the incremental treatment costs of AMR is largely attributed to inconsistencies in adjusting for critical covariates, such as hospital LOS prior to onset of infection, disease severity, and inappropriate antibiotic use. $(9,24,73)$ Using a risk bias assessment tool, Wozniak et al. determined that the best estimates for AMR bacteria-specific incremental treatment costs are currently available for methicillin-resistant S. aureus (MRSA), 3GCR-Enterobacteriaceae, and extended spectrum beta lactamase-producing (ESBL)+Enterobacteriaceae, ranging from 1600 EUR per MRSA blood-stream infection (BSI) (non-significant) to 9473 Swiss Francs (CHF) per ESBL+Enterobacteriaceae BSI. $(54,55,73)$ Excess LOS ranged from an additional 2.54 days per MRSA BSI (non-significant) to 6.8 days per ESBL+Enterobacteriaceae (significant). $(54,55)$

For the US, Thorpe et al. found that AMR added an average of 1,383 USD of incremental costs to bacterial infection treatment, and estimated an average annual national healthcare expenditure of 2.2 billion USD due to AMR.(61) The majority of these cost estimates were associated with increased costs of inpatient care, which reflects both additional LOS and additional cost of prescription drugs. This figure aligns with the US model produced by OECD.(43) The CDC reported a higher excess expenditure of 20 billion USD in annual healthcare costs and 35 billion USD in societal costs due to AMR.(27) The increased figures produced by the CDC may, in part, be due to the use of cost data from a single urban hospital in the USA which did not compare AMR infections to susceptible infections. (50)

Taken together, the majority of papers aimed at understanding the health and economic impact of AMR have consistently concluded that AMR is a major public health issue that will grow significantly if no effective national- and global-level action is implemented. Despite heterogeneity in estimates, the current and projected impacts of AMR demand urgent countermeasures. One such measure, advocated by WHO, World Organisation for Animal Health (OIE), and Food and Agriculture Organization (FAO), is the reduction and prospective restriction of AMU in animal agriculture. $(18,71,72)$ 


\section{Section 2: The impact of AMU in animal agriculture on AMR}

AMU in food animals is one of several factors that promotes AMR in both animals and humans. $(41,52,57)$ Many antimicrobials administered to food animals are the same as those utilized in human medicine. Genetic determinants that confer AMR can be transmitted among both commensal and pathogenic bacteria, including all zoonoses.(23) Pathways that transmit bacteria (and AMR bacteria) between humans and animals include direct contact, such as occupational exposure to animals, and indirect contact, such as foodborne and environmental routes of transmission.(68) The use of colistin in animal agriculture in China provides a recent example of emergence, selection, and widespread dissemination of genetic determinants of AMR as a probable consequence of AMU in animal agriculture.(67) Administration of colistin in food animals is believed to have selected for a novel resistance gene, $m c r-1$, in chicken and pig E. coli isolates in China, which has subsequently been reported in over 30 countries. $(36,65)$ Consequently, China has banned the use colistin administration in feed additives.(65)

In recent years, many countries, including the USA, Canada, Japan, and China, have limited, or restricted, the use of antibiotics in food animals. $(14,21,29,65)$ In some cases, such restrictions have been associated with reductions of AMR in humans, suggesting a causal relationship between AMU in animals and AMR in humans.(57) In this section, we first summarize the reasons for AMU in animals. Second, using the results of two independent reviews, commissioned by the WHO AGISAR, and the culminating WHO AGISAR report, we focus on the impact that restricting AMU in animals has on AMR in animals and humans.

\section{AMU in Animals}

Antimicrobial drugs are used in four different ways in food animals: treatment, metaphylaxis, prophylaxis and growth promotion.(44) Treatment uses are intended for animals with definitive signs or diagnostic tests that suggest a bacterial infection. Used interchangeably with "disease control," metaphylaxis is the process of administering antimicrobials to animals without clinical symptoms of infection that have been exposed to infected animals in the same population. A more liberal use of antimicrobials is prophylactic use, also known as "disease prevention." Prophylaxis is used to prevent animal disease among populations at risk of infection, although no animals display clinical illness and no infectious agent exposure is confirmed. Although prophylaxis and metaphylaxis antimicrobial regimens do not explicitly treat animals with clinical illness, these practices are widely believed to prevent disease and reduce economic costs for producers.(25) Lastly, growth promotion is the practice of administering antimicrobials to animals because they increase animal growth rates.

Using medically important antimicrobials (MIA) for growth promotion is regarded by the WHO, FAO, and OIE as an inappropriate AMU. $(18,71,72)$ These international agencies, among others, state that "treatment" is necessary for animal welfare and health; however, stakeholders have various tolerance to include metaphylactic, prophylactic, and growth promotion uses in the definition of "treatment." For example, the WHO's recommendation of a "complete restriction of use of all classes of medically important antimicrobials in food-producing animals for prevention of infectious diseases that have not yet been clinically diagnosed" has not resulted in similar commitments by FAO and OIE. Furthermore, there are concerns by some stakeholders that AMU labelled for prophylaxis or metaphylaxis instead may be used by some groups for purposes of growth promotion. 


\section{The impact of AMU in animal agriculture on AMR in animals}

Limiting AMU in food animals was associated with decreased prevalence of AMR bacteria in many studies.(52) A meta-analysis by Tang et al. described 179 studies aimed at assessing this effect.(57) One such study in Japan showed that following a voluntary withdrawal of a $3^{\text {rd }}$ generation cephalosporin in 2012, the prevalence of broad spectrum cephalosporin resistant E. coli (BSCR-E. coli) isolates from healthy broilers decreased from $16.4 \%$ in 2010 to 4.6\% 2013.(29) Using 81 of these studies, Tang et al. reported negative risk differences ranging from -1\% for cephalosporin resistant Enterobacteriaceae in fecal samples to $-39 \%$ for macrolide resistant Enterococcus spp. in fecal samples, corresponding to a 1$39 \%$ reduction in the proportion of AMR isolates among animals with restricted AMU compared to those with AMU.(57) The greatest risk difference was observed for Enterococcus spp. and the least for Campylobacter spp. The risk differences, although significant regardless of animal type, appeared greater in magnitude for interventions that targeted pigs and poultry, which are typically raised in intensive conditions where interventions occur at the herd or flock level. (57) The World Bank report noted that AMR in animals would over time likely result in lower livestock production due to greater prevalence of untreatable disease - a burden expected to be more pronounced in LMIC.(60)

\section{The impact of AMU in animal agriculture on AMR in humans}

Studies that directly aimed to address the association between restricted AMU in animals and reduced AMR bacteria in humans are more scarce, but supported a similar conclusion: AMU restriction in animals was associated with reduced AMR bacteria in humans.(41, 52, 57) Tang et al. found only 21 studies that assessed the impact of AMU restriction in food animals on AMR in humans. Scott et al. determined that only one study provided this evidence with credible effect sizes and time sequences.(52, 71) This single study showed that the voluntary withdrawal of ceftiofur use in chicken hatcheries in Canada in 2005, and partial re-introduction in 2007, was associated with respective decreases and increases in ceftiofur resistant-Salmonella Heidelberg in samples from both chicken meat and humans.(14) This temporal trend suggests a potential causal link between AMU in animal agriculture and AMR in humans. Tang et al., using data from 13 of these studies, concluded that the prevalence of AMR bacteria in human samples was $24 \%$ lower in the intervention group, where there was a reduced use of antibiotics in animals compared with the control group.(57) Due to the limited number of studies, Tang et al. did not produce isolate-level pooled risk differences stratified by bacterial species or sample type. The pooled risk difference was stronger in farm workers compared to humans without direct contact with livestock animals.(57) This finding is consistent with ongoing work in North Carolina, USA that demonstrates an increased risk of $S$. aureus, including multidrug-resistant $S$. aureus and MRSA, carriage and infections among industrial hog operation workers. $(26,66)$

Despite the limited evidence linking AMU in animals to AMR in humans, the WHO AGISAR strongly recommends, "an overall reduction in the use of all classes of MIA in food-producing animals," including a complete restriction on the use of MIA for growth promotion and disease prevention purposes.(71) It is important to note that determining causality between AMU in animals and AMR in humans requires studies designed around restrictions of AMU in animals, and thus must be conducted within critical windows of opportunity that are temporally aligned with state or national level regulatory or statutory action. For example, Senate Bill 27 in California, USA, effective in 2018, which banned AMU for the purpose of growth promotion and prohibited the use of MIA in livestock unless ordered by a veterinarian.(5) 


\section{Section 3: The fraction of AMR in humans attributable to animal agriculture}

AMR can spread to humans through "direct" and "indirect" pathways. In animal agriculture, direct pathways (i.e. animal contact) largely affect agricultural workers.(68) Conversely, indirect pathways largely involve consumer populations. Indirect exposures include animal food products and animal waste through contamination of groundwater.(68) The exact extent to which AMR in animals contributes to AMR infections in humans has not been established, primarily complicated by the bidirectional flow of genetic determinants of drug resistance that exists between animal and human pathogen populations. While the CDC have estimated that one in five AMR bacterial infections are linked to food or animals, an accurate fraction of AMR human infections attributable to livestock via all pathways may currently be infeasible.(27) Therefore, we focus our model parameterization on the human infections attributable to animal agriculture via a foodborne pathway.

Several countries have promulgated surveillance systems to monitor indirect, foodborne illness related infections, which in recent years have provided estimates on animal source attribution. Due to limitations in current and active surveillance for direct mechanisms, we can only review the proportion of human infections attributable to animals from foodborne illnesses.

An expert panel from the WHO was tasked with this question of AMR source attribution. We list results for three bacteria: Campylobacter, Salmonella, and E. coli. For complete, in-depth regional analysis, we refer readers to the WHO expert elicitation. Without exception, the primary source of human campylobacteriosis was poultry meat, accounting for $40 \%$ in European regions (EURO) to over 50\% in American, African (AFR) and Eastern Mediterranean (EMR) regions. Foodborne salmonellosis was caused by poultry products in over $30 \%$ of cases in the AFR and EMR regions. Among EURO regions and in a subregion of the Western Pacific and Southeast Asian region (SEAR), pork accounted for 15$20 \%$ of salmonellosis cases. Barring SEAR, E. coli foodborne illness was primarily attributed to beef, with over $25 \%$ of $E$. coli infections from beef products.(30)

The USDA, FDA, and CDC comprise the Interagency Food Safety Analytics Collaboration (IFSAC) - a surveillance system that surveys foodborne illness via outbreak data in the USA. Using data from 1998 through 2016 in the USA, IFSAC reported that 9 million people fall ill, 56,000 are hospitalized, and 1,300 die of foodborne disease, annually.(31) Over 75\% of 2016 Salmonellosis illnesses were from seven food categories, and the second-largest source (behind seeded vegetables) was chicken (12.7\%).(31) In 2016, over 70\% of E. coli O157 outbreaks were sourced from vegetable crops and beef, and over $70 \%$ of L. monocytogenes cases were from consumption of dairy and fruit. In 2016, chicken was the primary source for non-dairy related campylobacteriosis cases at $47.5 \%$.(31) Contemporaneously, the National Food Institute attributed $46 \%$ of $C$. jejuni cases in Denmark to domestic chicken, $19 \%$ to cattle, and $9 \%$ to imported chicken.(47) Because multiple factors are associated with the attributable fraction, estimates likely vary among countries.(30)

Regional- and national-level surveillance systems for foodborne pathogens estimate the proportion and total number of infections attributable to animal agriculture. Such surveillance systems are currently best exemplified by the North American and EU/EEA systems. However, surveillance systems should be expanded to comprehensively monitor AMR bacteria attributable to animal agriculture contracted via direct routes of exposure (e.g. occupation workers) and other, non-foodborne environmental routes of exposure (e.g. contaminated waterways).(15) 


\section{Section 4: AMU in Animals}

Properly estimating the effects of AMU in animal agriculture requires data on the use of antimicrobials. The ideal dataset would report the exact dose of active antimicrobial ingredient administered, the number of animals that received them and the exact reasons. Unfortunately, AMU data in animal agriculture are largely unavailable in most countries. Cuong et al. provides one of the only reviews of AMU in animal agriculture across all countries worldwide.(11) Many of the reviewed manuscripts do not elucidate exact AMU amounts, and therefore cannot be incorporated into our proposed economic model. Inclusion would also require the data to be stitched together across studies, which, even collectively, may not accurately represent the target population. As a substitute, this section focuses on "antimicrobial sales" (AMS) to the domestic animal agriculture sector, on which there is significantly more data available. Supplemental material S3 and S4 describe methodologies for data acquisition and the trends and projections described in the reviewed material. The total kilograms (kgs) of antibiotics bought by the animal agriculture sector within a country will necessarily be less than or equal to what is used in the sector.

\section{Global Use of Antimicrobials in Mainly Food-Producing Animals}

The US sells more antimicrobial agents to its domestic animal population, both MIA and nonmedically important (NMIA), than any other country (10.9 million $\mathrm{kg}$ ), about $40 \%$ more than the entirety of the European Union (EU) (7.79 million kg), according to compiled country and region-reported data. $(12,17)$ About $50 \%$ of AMS in the USA were NMIA $(5.4$ million $\mathrm{kg}$ ), whereas the EU sold no NMIA for use in animal agriculture. $(12,17)$ This means in consideration to MIA, the EU sold $30 \%$ more antimicrobials than the US to the animal agriculture sector.

All other countries reported official AMS data at fractions of those found in the US and EU. However, estimates for China have ranged from 6 million kgs in 2001to 84.2 million kgs in 2013 - with upper limits around $8 \mathrm{x}$ more than the US and 11x more than the EU (Table $4 b) .(16,74)$ These figures for China are highly disparate from the OIE estimates of the entire Asian continent, estimated to be about 3 million kg. (Table 4a,b)

Comparison of sales of individual classes of antimicrobial drugs by weight demonstrates that tetracyclines are the largest AMS, and make up 51\% of all antimicrobials by weight sold in Canada, $47 \%$ in Japan, 33\% in Korea, 32\% in the US, $29 \%$ in the EU, and 9\% in Australia.(1, 8, 12, 17, 39, 49) Tetracyclines are sold $4 \mathrm{x}$ more than any other antimicrobial class in countries that reported sales to animal agriculture (Table 4a). The antimicrobial class with lowest sales is cephalosporins, which contribute $0.3 \%$ of total sales among countries surveyed and under $1 \%$ of the composition of each individual countries' AMS. However, comparisons by weight do not take the relative potencies of the drugs into account; some antimicrobials require either lower concentrations or a smaller dose (by weight) than others to achieve the same health or production endpoints.

Given different dosing requirements for different species of animals, estimates of AMS or AMU should ideally be stratified by animal species and standardized to the total number of that animal species raised for meat. This standardization would allow direct comparisons of antimicrobials sold (and used) per animal produced in each sector of animal agriculture among different countries, and may give insights into use-, animal husbandry-, and animal welfare practices. A Natural Resources Defense Council (NRDC) report estimated that in 2017, the US used $155.5 \mathrm{mg}$ of antibiotics / $\mathrm{kg}$ of livestock (mgA/ $\mathrm{kgL}$ ), 
whereas some EU countries used $40.8 \mathrm{mgA} / \mathrm{kgL}$ (Denmark), and $45.0 \mathrm{mgA} / \mathrm{kgL}$ (United Kingdom).(32) However, other countries such as Italy and Spain consume about 2x more per kg of livestock than USA, $294.8 \mathrm{mgA} / \mathrm{kgL}$ and $362.5 \mathrm{mgA} / \mathrm{kgL}$ respectively. $(32,64)$ However, animals may have different dosing requirements according to relative size, species, and age, related in part to different pharmacokinetics and pharmacodynamics. In the pork industry, NRDC reports that the USA devotes $338 \mathrm{mgA} / \mathrm{kgP}$ of MIA to pigs compared to $183 \mathrm{mgA} / \mathrm{kgP}$ sold in the UK and only $(44 \mathrm{mgA} / \mathrm{kgP})$ in the Netherlands and Denmark.(63)

\section{Section 5: Economic model of Externalities}

AMR represents a negative externality, i.e. it is a side effect of AMU that affects all members of society without being reflected in the market price of antimicrobials. $(3,35)$ To guide public policy on AMU, it is crucial to evaluate the magnitude of this externality, but to our knowledge, no studies to date have estimated the externality costs of AMR resulting from AMU in animals. We combine an economic model of the cost of resistance for humans with an evolutionary model of resistance dynamics to antimicrobials in order to capture the externalities of AMR. For detailed derivations, we refer the reader to an online technical note.(33)

\section{Model Setup}

We consider a model in which there are two separate pools of pathogens, i.e. a human and a food animal pool, labeled by subscripts $h$ and a, between which diffusion of pathogens occurs in line with the pathways described in Section 3. In our context, taking the overall prevalence of pathogens in each pool as given is a reasonable simplifying assumption and allows us to focus on resistance rates of pathogens in each pool, denoted by $\mathrm{x}_{\mathrm{h}}$ and $\mathrm{x}_{\mathrm{a}}$.

\section{Food animal pool}

Consider first the pathogen pool among food animals and assume that an amount $\mathrm{m}_{\mathrm{a}}$ of antimicrobials is applied each period, creating selective pressure $s_{a}$ per unit on the fraction $\left(1-x_{a}\right)$ of non-resistant pathogens in the pool, which creates a force that increases resistance. We denote the total effective exposure by $e_{a}=m_{a} \cdot s_{a}$. Conversely, assume that the trait that confers resistance carries a fitness cost $f_{a}$ on the fraction $\mathrm{x}_{\mathrm{a}}$ of resistant pathogens when no antimicrobial is administered. Given the two opposing forces, the change in the resistance rate of pathogens in the food animal pool is given by

$$
\dot{x}_{\mathrm{a}}=\left(1-\mathrm{x}_{\mathrm{a}}\right) \cdot\left[\mathrm{e}_{\mathrm{a}}-\mathrm{f}_{\mathrm{a}} \cdot \mathrm{x}_{\mathrm{a}}\right]
$$

We focus on steady states of the system to keep our analysis as clear and tractable as possible, i.e. we assume that the resistance rates have converged to the level at which they would arrive if the environment and the input of antimicrobials were held constant for an extended period of time so $\dot{x}_{\mathrm{a}}=0$.

If the fitness cost of resistance is less than the effective exposure $\left(f_{a} \leq e_{a}\right)$, then resistant pathogens win out and the system converges toward full resistance so $\mathrm{x}_{\mathrm{a}}=1$ in the long run. On the other hand, if the fitness cost surpasses the effective exposure, resistance converges to $x_{a}=e_{a} / f_{a}<1$. This is the case in the example data shown next. Resistance is then linear in the effective exposure $e_{a}$ of the food animal pool and by implication, for given $\mathrm{s}_{\mathrm{a}}$, in the amount of antimicrobial applied $\mathrm{m}_{\mathrm{a}}$. 


\section{Human pool}

Let us next consider the resistance rate $\mathrm{x}_{\mathrm{h}}$ in the pathogen pool of humans. As in the food animal pool, the human pool experiences effective exposure $e_{h}$ to antimicrobials given to humans, and resistance carries a fitness cost $\mathrm{f}_{\mathrm{h}}$. In addition, pathogens from the food animal pool diffuse into the human pool at rate $\mathrm{d}$, and a fraction $\mathrm{x}_{\mathrm{a}}$ of these pathogens is resistant. The change in the overall resistance rate of pathogens in the human pool thus contains an extra term,

$$
\dot{x}_{\mathrm{h}}=\left(1-\mathrm{x}_{\mathrm{h}}\right) \cdot\left[\mathrm{e}_{\mathrm{h}}-\mathrm{f}_{\mathrm{h}} \cdot \mathrm{x}_{\mathrm{h}}\right]+\mathrm{d} \cdot\left[\mathrm{x}_{\mathrm{a}}-\mathrm{x}_{\mathrm{h}}\right]
$$

To better relate our model to the data, let us separately denote the fraction of resistant pathogens in the human pool that originates directly from the food animal pool by $\mathrm{y}_{\mathrm{h}}$, which satisfies by definition $\mathrm{y}_{\mathrm{h}} \leq \mathrm{x}_{\mathrm{h}}$. This fraction is driven solely by the fitness cost and the diffusion dynamics,

$$
\dot{y}_{\mathrm{h}}=-\left(1-\mathrm{x}_{\mathrm{h}}\right) \cdot \mathrm{f}_{\mathrm{h}} \cdot \mathrm{y}_{\mathrm{h}}+\mathrm{d} \cdot\left[\mathrm{x}_{\mathrm{a}}-\mathrm{y}_{\mathrm{h}}\right]
$$

Focusing on steady states with $\dot{x}_{\mathrm{h}}=\dot{y}_{\mathrm{h}}=0$ allows us to solve the resulting two steady-state equations for the normalized diffusion and exposure rates $\mathrm{d} / \mathrm{f}_{\mathrm{h}}$ and $\mathrm{e}_{\mathrm{h}} / \mathrm{f}_{\mathrm{h}}$ as a function of the observed levels of $\mathrm{x}_{\mathrm{a}}, \mathrm{x}_{\mathrm{h}}$ and $\mathrm{y}_{\mathrm{h}}$. We can then apply the implicit function theorem to the system of steady-state equations to determine the marginal effect of greater resistance among food animals on the resistance rate among humans,

$$
\frac{d x_{h}}{d x_{a}}=\frac{y_{h}}{x_{a}} \cdot \frac{x_{h}-y_{h}}{x_{a}-y_{h}}
$$

and by implication the marginal effect of antimicrobial application in the food animal pool for resistance among humans,

$$
\frac{d x_{h}}{d m_{a}}=\frac{s_{a}}{f_{a}} \cdot \frac{d x_{h}}{d x_{a}}=\frac{s_{a}}{f_{a}} \cdot \frac{y_{h}}{x_{a}} \cdot \frac{x_{h}-y_{h}}{x_{a}-y_{h}}
$$

\section{Externality Cost of Resistance}

Denote by $\mathrm{C}$ the excess cost of resistant human infections over susceptible infections and by $\mathrm{D}$ the disease burden among humans, captured as cases per year, a fraction $\mathrm{x}_{\mathrm{h}}$ of which are resistant. Then the total human welfare loss from AMR is given by

$$
W=-C \cdot D \cdot x_{h}
$$

The human welfare effect of greater AMR in the animal pool is given by

$$
\frac{d W}{d x_{a}}=-C \cdot D \cdot \frac{d x_{h}}{d x_{a}}
$$

The negative social externalities from the use of antimicrobials $m_{a}$ in the food animal sector can be captured by the marginal effect

$$
\frac{d W}{d m_{a}}=-C \cdot D \cdot \frac{d x_{h}}{d m_{a}}
$$

\section{Parameterization}

We parameterize our model to capture how fluoroquinolone (FQ) application to broiler chickens (hereafter: chickens) affected the resistance of Campylobacter in humans using 1999 data, i.e. prior to the phasing out FQ in chicken production in the USA. The Center for Veterinary Medicine proposed the 
withdrawal of FQ in poultry water in 2000, after an FDA risk analysis determined that the use of FQ in poultry caused the development of FR-Campylobacter infections in humans.(20) The FDA's final decision to withdraw approval of enrofloxacin for use in poultry became effective in 2005.(10)

\begin{tabular}{|l|c|c|}
\hline Description & Variable & Value \\
\hline Excess dollar cost per FR human Campylobacter infection & $\mathrm{C}$ & $\$ 1961(61)$ \\
\hline Number of human Campylobacter infections administered FQ & $\mathrm{D}$ & $94,462(20)$ \\
\hline Fraction of human Campylobacter infections with FR & $\mathrm{x}_{\mathrm{h}}$ & $18.0 \%(7)$ \\
\hline $\begin{array}{l}\text { Fraction of human Campylobacter infections attributable to } \\
\text { chickens }\end{array}$ & $\mathrm{y}$ & $54 \%(7,20)$ \\
\hline Fraction of FR Campylobacter isolates in retail chickens & $\mathrm{x}_{\mathrm{a}}$ & $24 \%(20)$ \\
\hline Active enrofloxacin applied to chickens & $\mathrm{m}_{\mathrm{a}}$ & $6786 \mathrm{~kg}(13,46,48)$ \\
\hline
\end{tabular}

Table 1: Input parameters for externality model. Parameters specific to Campylobacter infections, fluoroquinolone resistance, and fluoroquinolone use in broiler chickens are extracted from US reports and scientific manuscripts.

The input parameters for our model are summarized in Table 1. The excess dollar cost per FR human infection (C) was extracted from Thorpe et al., and estimated as the incremental expense that AMR adds to treating a bacterial infection (excluding UTIs) in the US, deflated from 2014 to 1999 using the GDP deflator for consistency with Thorpe et al.(61) An FDA risk analysis published in 2000 reports 1.60m human Campylobacter cases in 1999 (p.20), of which 856k were attributable to chickens (p.21), yielding a fraction $\mathrm{y}=54 \%$. Furthermore, $50.5 \mathrm{k}$ of chicken-attributable cases were administered FQ (p.21). Assuming the same proportion in all human cases, we extrapolate that $\mathrm{D}=94.5 \mathrm{k}$ Campylobacter patients were administered FQ.(20) The fraction $\mathrm{x}_{\mathrm{h}}$ of Campylobacter infections in humans with FR was obtained from the NARMS 1999 report.(7) The fraction $\mathrm{x}_{\mathrm{a}}$ of FR-Campylobacter isolates in retail chickens was extracted from Section V.B of the FDA risk analysis.(20)

The total amount of enrofloxacin administered to chickens was obtained by multiplying the number of chickens who received Baytril for metaphylaxis in 1999 (a range of 93.5m - 136m as estimated by FDA), the dosage of $25-50 \mathrm{mg} / 1$ enrofloxacin in drinking water, an average daily water intake of growing chickens of 0.1431 , and the dosing period of 3-7 days. The daily water intake was obtained by multiplying the mean age of broiler chickens of 27 days (given that they were slaughtered at 8 weeks with a 2-day withdrawal period for enrofloxacin administration) with a water-intake of $5.28 \mathrm{ml}$ per day of age. $(13,46,48)$ Since the total amount of enrofloxacin administered to chickens enters our externality estimate in the denominator (via the parameter $\mathrm{s}_{\mathrm{a}} / \mathrm{f}_{\mathrm{a}}=\mathrm{x}_{\mathrm{a}} / \mathrm{m}_{\mathrm{a}}$ ), lower amounts of $\mathrm{kg}$ used lead to higher externality estimates per kg. For our baseline analysis, we thus conservatively employed the high point of the ranges we listed and performed robustness analyses on the implications of using lower values for the AMU data. 
Before reporting our results let us note three caveats to our analysis. First, our data relies on a number of parameter estimates, and of course our results are only as reliable as our inputs. However, given the simplicity of our formulas, it is easy to conduct robustness exercises by varying the parameters. A spreadsheet which the reader can employ to perform robustness analysis is available at http://www.korinek.com/AMR. Secondly, our model evaluation assumed that the 1999 data reflected a steady state; this made the analysis significantly more transparent but may have biased our externality estimates downwards if in fact resistance rates had continued to climb in the absence of action. Third, our externality estimate cannot directly be used as a corrective tax on AMU in animal agriculture (in the spirit of a Pigouvian tax in economics) since imposing the tax would likely reduce AMU and alter the steady state and the magnitude of the associated externality.

\section{Results}

Our main results can be summarized as follows. First, the total excess human cost from FRCampylobacter infections was $\$ 33 \mathrm{~m}$ in 1999 , of which $\$ 18 \mathrm{~m}$ were attributable to chickens. Second, an additional percentage point of FR among chickens would have generated, at the margin, an extra 0.23 percentage points resistance among humans and $\$ 435 \mathrm{k}$ in extra social costs from treating resistant infections in humans. Third, an additional kilogram of enrofloxacin administered to chickens imposed an externality cost of about $\$ 1500$ on human society, which translated into a 7-cent social cost per chicken

just from FR-Campylobacter alone. This externality represented a cost on society that was not captured in the price of either the antimicrobial or the chickens sold in the marketplace and, because of the nature of externalities, may have led to overuse of FQ in broiler chickens compared to what was desirable from a societal perspective.

For robustness, we analyze the implications of using estimates on the use of enrofloxacin that are informed by the lower ranges listed in the parameterization above. For example, if we employ the estimate of $93.5 \mathrm{~m}$ chickens to which enrofloxacin was applied, the total amount of enrofloxacin used was $4,665 \mathrm{~kg}$, and our externality estimate is about $\$ 2200$ per kilogram used.

\section{Discussion}

Preventing unnecessary AMU in animal production is frequently cited as a key strategy for curbing AMR, but the potential human health costs of AMU in animal production have not previously been quantified. We reviewed the existing literature and proposed an evolutionary and economic model of resistance dynamics and the resulting externalities to quantify the costs of AMU in animal production on AMR in humans.

As a proof of concept, we applied this model to estimate the excess costs borne by US society as a result of using fluoroquinolones in broiler chicken production in 1999. The introduction of enrofloxacin to US broiler chickens was a unique, landmark case that provided critical insights into the potential downsides of AMU in animal production. First, this antimicrobial was introduced to poultry production during a time when the FDA and CDC actively monitored antimicrobial resistance in Campylobacter from poultry products and human infections. Second, campylobacteriosis in the USA were largely attributable to poultry products. Third, the FDA could estimate enrofloxacin sales in USA poultry production. All of these factors enabled the FDA and CDC to recognize a causal relationship between 
introduction of enrofloxacin for use in broiler chickens and FR-campylobacteriosis in humans. These factors also made this an excellent test case for our externalities approach. However, it should be noted that Campylobacter is just one of many zoonotic pathogens under the selection of AMU in food animals. Likewise, fluoroquinolones are just one of many antimicrobial classes that have been used and potentially overused in food-animal production since the 1940s.

The FDA has taken several important steps since the late 1990s to reduce the public health risks associated with AMU in food animals. Guidance for Industry (GFI) \#152 laid out industry guidelines for assessing AMR-related human health risks before new antimicrobials could be introduced to food-animal production. While GFI \#152 substantially increased requirements for new antimicrobials to food-animal production, it was not applied to previously-approved antimicrobials. Therefore, the FDA subsequently began a series of steps to restrict some of the antimicrobials most important to human medicine, including prohibitions on extra-label uses of fluoroquinolones and cephalosporins and eventually the prohibition of fluoroquinolone use in broiler chicken production. In 2013, the FDA initiated a successful voluntary program to eliminate antimicrobial growth promotion claims, effectively making this use illegal. Finally, in 2015 the FDA implemented the Veterinary Feed Directive (VFD) amendment that required a veterinary prescription to administer antimicrobials in feed. Together, these steps have likely decreased the potential negative human health consequences of AMU in food animals. (For further descriptions of FDA policies for AMR guidance, see Supplementary Materials S5). However, the FDA has not eliminated routine AMU in US food animals. In 2017, more than 5.5 million kgs of medically-important antimicrobials were sold for use in US food-animal production. The vast majority of these drugs were tetracyclines administered to pigs and cattle as feed supplements.

Despite calls by global leaders to decrease antimicrobial use in food animals, projections indicate that AMU in food-animal production will increase substantially in LMIC over the next two decades.(2) These projections are founded on the observation that economic development leads to more meat consumption, which drives the industrialization food-animal production and, in turn, drives more antimicrobial consumption. While the US model for industrialized food-animal production has been replicated around the world, the FDA's nuanced approach to restricting some antimicrobials while allowing others to be used extensively has not. Instead, it appears that antimicrobials from across the spectrum of medical importance are used routinely in LMIC.(2) The potential for harm from nonjudicious AMU in food animals may be greatest among LMIC, where poor environmental controls and weak food safety regulations facilitate the transmission of bacteria between food animals and humans. LMICs may also have fewer resources to detect and address extensively resistant zoonotic infections.

We intend the approach presented in this paper to serve as a foundation for future analyses to quantify the external costs associated with AMU in food-animal production, including with resistance to other antimicrobials and across other pathogens, other livestock species, and other countries or contexts. Externalities, if unregulated, are by definition not currently reflected in the cost of antimicrobials used in food animal production and may thus provide incentives for overuse. We hope that better understanding of the external costs of AMU in food animals will help to inform the policy debate on the topic and help to balance the important societal functions of food-animal production with the risks of AMR to society. 


\section{References}

1. Australian Pesticides and Veterinary Medicines Authority. Quantity of Antimicrobial Products Sold for Veterinary Use in Australia.; 2014.

2. Van Boeckel TP, Brower C, Gilbert M, et al. Global trends in antimicrobial use in food animals. Proc Natl Acad Sci U S A. 2015;112(18):5649-5654. doi:10.1073/pnas.1503141112.

3. Brown G, Layton DF. Resistance economics: social cost and the evolution of antibiotic resistance. Environ Dev Econ. 1996;1(3):349-355.

4. Burnham JP, Olsen MA, Kollef MH. Re-estimating annual deaths due to multidrug-resistant organism infections. Infect Control Hosp Epidemiol. 2019;40(1):112-113. doi:10.1017/ice.2018.304.

5. California Legislative Body. Senate Bill No. 27 Livestock: Use of Antimicrobial Drugs. California Legislative Counsel; 2015. https://leginfo.legislature.ca.gov/faces/billTextClient.xhtml?bill_id=201520160SB27

6. Cassini A, Högberg LD, Plachouras D, et al. Attributable deaths and disability-adjusted life-years caused by infections with antibiotic-resistant bacteria in the EU and the European Economic Area in 2015: a population-level modelling analysis. Lancet Infect Dis. 2019;19(1):56-66. doi:10.1016/S1473-3099(18)30605-4.

7. CDC, FDA. NARMS 1999 Annual Report.; 1999. https://www.cdc.gov/narms/annual/1999/NARMS_final_report_1999_full.pdf.

8. CIPARS. Canadian Integrated Program for Antimicrobial Resistance Surveillance (CIPARS), 2016 Annual Report.; 2016.

9. Cohen B, Larson EL, Stone PW, Neidell M, Glied SA. Factors Associated With Variation in Estimates of the Cost of Resistant Infections. Med Care. 2010;48(9):767-775. doi:10.1097/MLR.0b013e3181e358b9.

10. Crawford LM. Enrofloxacin for Poultry; Final Decision on Withdrawal of New Animal Drug Application Following Formal Evidentiary Public Hearing; Availability.; 2005.

11. Cuong N, Padungtod P, Thwaites G, Carrique-Mas J. Antimicrobial Usage in Animal Production: A Review of the Literature with a Focus on Low- and Middle-Income Countries. Antibiotics. 2018;7(3):75. doi:10.3390/antibiotics7030075.

12. CVM, FDA. 2017 Summary Report On Antimicrobials Sold or Distributed for Use in FoodProducing Animals.; 2017. https://www.fda.gov/media/119332/download. Accessed May 7, 2019.

13. Davidson DJ. Proposal to Withdraw Approval of The New Annimal Drug Application for Enrofloxacin for Poultry.; 2000.

14. Dutil L, Irwin R, Finley R, et al. Ceftiofur resistance in Salmonella enterica serovar Heidelberg from chicken meat and humans, Canada. Emerg Infect Dis. 2010;16(1):48-54. doi:10.3201/eid1601.090729.

15. Economou V, Gousia P. Agriculture and food animals as a source of antimicrobial-resistant bacteria. Infect Drug Resist. 2015;8:49-61. doi:10.2147/IDR.S55778.

16. Ellis LJ, Turner JL. Environmental and food safety concerns of China's aquaculture and animal husbandry. China Environ Ser. 2007;9:19-42. 
17. European Medicines Agency (EMA). Sales of Veterinary Antimicrobial Agents in 30 European Countries. Trends from 2010 to 2016. Eighth ESVAC Report.

https://www.ema.europa.eu/en/documents/report/sales-veterinary-antimicrobial-agents-30european-countries-2016-trends-2010-2016-eighth-esvac_en.pdf. Accessed May 7, 2019.

18. FAO. Supporting the food and agriculture sectors in implementing the Global Action Plan on Antimicrobial Resistance to minimize the impact of antimicrobial resistance. In: Rome. www.fao.org/publications. Accessed May 27, 2019.

19. FDA/CVM. Guidance for Industry \#152 - Evaluating the Safety of Antimicrobial New Animal Drugs with Regard to Their Microbiological Effects on Bacteria of Human Health Concern October 23, 2003.; 2003.

http://www.fda.gov/AnimalVeterinary/GuidanceComplianceEnforcement/GuidanceforIndustry/d

20. FDA/CVM. Human Health Impact of Fluoroquinolone Resistant Campylobacter Attributed to the Consumption of Chicken.; 2000.

21. Food and Drug Administration. Veterinary Feed Directive. Fed Regist. 2015;80(106):3170831735 .

22. Food and Drug Administration (FDA). List of Medically Important Antimicrobial Drugs Affected by GFI \#213. https://www.fda.gov/animal-veterinary/judicious-use-antimicrobials/list-medicallyimportant-antimicrobial-drugs-affected-gfi-213. Accessed May 7, 2019.

23. Frieri M, Kumar K, Boutin A. Antibiotic Resistance. J Infect Public Health. 2017;10:369—378. doi:10.1016/j.cell.2018.02.018.

24. Gandra S, Barter DM, Laxminarayan R. Economic burden of antibiotic resistance: How much do we really know? Clin Microbiol Infect. 2014;20(10):973-980. doi:10.1111/1469-0691.12798.

25. Hao H, Cheng G, Iqbal Z, et al. Benefits and risks of antimicrobial use in food-producing animals. Front Microbiol. 2014;5:288. doi:10.3389/fmicb.2014.00288.

26. Hatcher SM, Rhodes SM, Stewart JR, et al. The Prevalence of Antibiotic-Resistant Staphylococcus aureus Nasal Carriage among Industrial Hog Operation Workers, Community Residents, and Children Living in Their Households: North Carolina, USA. Environ Health Perspect. 2017;125(4):560-569. doi:10.1289/EHP35.

27. HHS/CDC. Antibiotic Resistance Threats in the United States, 2013. Atlanta; 2013. https://www.cdc.gov/drugresistance/threat-report-2013/pdf/ar-threats-2013-508.pdf. Accessed August 16, 2018.

28. HHS/FDA. Guidance for Industry The Judicious Use of Medically Important Antimicrobial Drugs in Food-Producing Animals.; 2012.

http://www.regulations.gov.allhttp//www.fda.gov/AnimalVeterinary/GuidanceComplianceEnforce ment/GuidanceforIndustry/default.htmorhttp://www.regulations.gov. Accessed August 16, 2018.

29. Hiki M, Kawanishi M, Abo H, et al. Decreased Resistance to Broad-Spectrum Cephalosporin in Escherichia coli from Healthy Broilers at Farms in Japan After Voluntary Withdrawal of Ceftiofur . Foodborne Pathog Dis. 2015;12(7):639-643. doi:10.1089/fpd.2015.1960.

30. Hoffmann S, Devleesschauwer B, Aspinall W, et al. Attribution of global foodborne disease to specific foods: Findings from a World Health Organization structured expert elicitation. PLoS One. 2017;12(9). doi:10.1371/JOURNAL.PONE.0183641.

31. IFSAC. Interagency Food Safety Analytics Collaboration. Foodborne illness source attribution 
estimates for 2013 for Salmonella, Escherichia coli O157, Listeria monocytogenes, and Campylobacter using multi-year outbreak surveillance data, United States. GA and D. IFSAC Proj. 2017;(November):1-13. https://www.cdc.gov/foodsafety/pdfs/IFSAC2013FoodborneillnessSourceEstimates-508.pdf.

32. Kar A, Wallinga D. Livestock Antibiotic Sales See Big Drop, but Remain High|NRDC.; 2018. https://www.nrdc.org/experts/avinash-kar/livestock-antibiotic-sales-drop-remain-very-high. Accessed May 7, 2019.

33. Korinek A. The Externalities of Antimicrobial Resistance, http://www.korinek.com/AMR. Published 2019.

34. KPMG. The global economic impact of anti-microbial resistance. Kpmg. 2014;(December):1-44.

35. Laxminarayan R, Brown GM. Economics of Antibiotic Resistance: A Theory of Optimal Use. J Environ Econ Manage. 2001;42(2):183-206.

36. Liu Y-Y, Wang Y, Walsh TR, et al. Emergence of plasmid-mediated colistin resistance mechanism MCR-1 in animals and human beings in China: a microbiological and molecular biological study. Lancet Infect Dis. 2016;16(2):161-168. doi:10.1016/S1473-3099(15)00424-7.

37. Matsunaga N, Hayakawa K. Estimating the impact of antimicrobial resistance. Lancet Glob Heal. 2018;6(9):e934-e935. doi:10.1016/S2214-109X(18)30325-5.

38. Mcdermott P, Tate H, Friedman C, et al. NARMS 2015 Integrated Report.; 2015. https://www.fda.gov/AnimalVeterinary/SafetyHealth/AntimicrobialResistance/NationalAntimicro bialRe. Accessed August 16, 2018.

39. Ministry of Agriculture Forestry and Fisheries (MAFF). Sales Amounts and Sales Volumes (Active Substance) of Antibiotics, Synthetic Antibacterials, Antihelmintics and Antiprotozoals. Japan; 2015. http://www.maff.go.jp/nval/iyakutou/hanbaidaka/attach/pdf/h27-koukinzai_re.pdf. Accessed May 8, 2019.

40. Naylor NR, Atun R, Zhu N, et al. Estimating the burden of antimicrobial resistance: a systematic literature review. Antimicrob Resist Infect Control. 2018;7(1):1-17. doi:10.1186/s13756-018-0336y.

41. O'Neill J. AMR Review Paper-Tackling a crisis for the health and wealth of nations. AMR Rev Pap. 2014;(December).

42. O’Neill J. Review on Antimicrobial Resistance. Tackling drug-resistant infections globally. Who. 2016;(May):11.

43. OECD. Stemming the Superbug TideL Just a Few Dollars More. Paris; 2018. doi:10.1787/9789264307599-en.

44. Office USGA. ANTIBIOTIC RESISTANCE Agencies Have Made Limited Progress Addressing Antibiotic Use in Animals Report to the Ranking Member, Committee on Rules, House of Representatives.; 2011. https://www.gao.gov/assets/330/323090.pdf. Accessed May 7, 2019.

45. OIE. OIE Annual Report on Antimicrobial Agents Intended for Use in Animals: Better Understanding of the Global Situation. Paris; 2017.

46. Pesti GM, Amato S V., Minear LR. Water Consumption of Broiler Chickens Under Commercial Conditions. Poult Sci. 1985;64(5):803-808. doi:10.3382/ps.0640803.

47. Pires SM, Christensen J. Source attribution of Campylobacter infections in Denmark Technical 
Report. Natl Food Institute, Tech Univ Denmark. 2017.

48. Plumb DC. Veterinary Drug Handbook. Third Edit. White Bear Lake, Minnesota: PHarma Vet Publishing; 1999.

49. $\quad$ QIA. Establishment of Monitoring System for Livestock Antibiotics for Livestock in 2012:

Antibiotic Use and Antibiotic Resistance Monitoring.

http://lib.qia.go.kr/LibtechUpload/Book/B20140306-2.pdf. Accessed May 8, 2019.

50. Roberts RR, Hota B, Ahmad I, et al. Hospital and Societal Costs of Antimicrobial $\square$ Resistant Infections in a Chicago Teaching Hospital: Implications for Antibiotic Stewardship. Clin Infect Dis. 2009;49(8):1175-1184. doi:10.1086/605630.

51. Schneeweiss S, Robicsek A, Scranton R, Zuckerman D, Solomon DH. Veteran's affairs hospital discharge databases coded serious bacterial infections accurately. J Clin Epidemiol.

2007;60(4):397-409. doi:10.1016/j.jclinepi.2006.07.011.

52. Scott AM, Beller E, Glasziou P, et al. Is antimicrobial administration to food animals a direct threat to human health? A rapid systematic review. Int J Antimicrob Agents. 2018;52(3):316-323. doi:10.1016/j.ijantimicag.2018.04.005.

53. Shrestha P, Cooper BS, Coast J, et al. Enumerating the economic cost of antimicrobial resistance per antibiotic consumed to inform the evaluation of interventions affecting their use. Antimicrob Resist Infect Control. 2018;7(1):98. doi:10.1186/s13756-018-0384-3.

54. Stewardson A, Fankhauser C, Augelis G De, et al. Burden of Bloodstream Infection Caused by Extended-Spectrum $\beta$-Lactamase-Producing Enterobacteriaceae Determined Using Multistate Modeling at a Swiss University Hospital and a Nationwide Predictive Model. Infect Control Hosp Epidemiol. 2013;34(2):133-143. doi:10.1086/669086.

55. Stewardson AJ, Allignol A, Beyersmann J, et al. The health and economic burden of bloodstream infections caused by antimicrobial-susceptible and non-susceptible Enterobacteriaceae and Staphylococcus aureus in European hospitals, 2010 and 2011: a multicentre retrospective cohort study . Eurosurveillance. 2016;21(33). doi:10.2807/1560-7917.es.2016.21.33.30319.

56. Sue Binder S. The National Food Safety Initiative. Emerg Infect Dis. 1998;4(2):347-349. doi:10.3201/eid0402.980239.

57. Tang KL, Caffrey NP, Nóbrega DB, et al. Restricting the use of antibiotics in food-producing animals and its associations with antibiotic resistance in food-producing animals and human beings: a systematic review and meta-analysis. Lancet Planet Heal. 2017;1(8):e316-e327. doi:10.1016/S2542-5196(17)30141-9.

58. Taylor J, Hafner M, Yerushalmi E, et al. Estimating economic costs of antimicrobial resistance: Model and Results. RAND Eur. 2014:1-113.

59. Temkin E, Fallach N, Almagor J, et al. Estimating the number of infections caused by antibioticresistant Escherichia coli and Klebsiella pneumoniae in 2014: a modelling study. Lancet Glob Heal. 2018;6(9):e969-e979. doi:10.1016/S2214-109X(18)30278-X.

60. The World Bank. Drug-resistant infections: A Threat to Our Economic Future. World Bank Rep. 2017;(September):1-132. doi:10.1007/s11947-009-0181-3.

61. Thorpe KE, Joski P, Johnston KJ. Antibiotic-Resistant Infection Treatment Costs Have Doubled Since 2002, Now Exceeding \$2 Billion Annually. Health Aff. 2018;37(4):662-669.

doi:10.1377/hlthaff.2017.1153. 
62. United States Department of Agriculture (USDA) Foreign Agriculture Service (FAS). Country Production Total Exports Livestock and Poultry: World Markets and Trade China's Share of World Meat Imports to Expand in 2019.; 2019. https://apps.fas.usda.gov/psdonline/circulars/livestock_poultry.pdf. Accessed May 7, 2019.

63. Wallinga D. Better bacon why it's high time the US pork Industry stopped pigging out on antibiotics. 2018;(May). https://www.nrdc.org/resources/better-bacon-why-its-high-time-us-porkindustry-stopped-pigging-out-antibiotics.

64. Wallinga D, Roach S. Antibiotic Consumption in U.S. Pork, Beef, and Turkey Industries Vastly Outstrips Comparable Industries in Europe, and the U.S. Chicken Industry | NRDC. 2018;(November). https://www.nrdc.org/resources/antibiotic-consumption-us-pork-beef-andturkey-industries-vastly-outstrips-comparable.

65. Walsh TR, Wu Y. China bans colistin as a feed additive for animals. Lancet Infect Dis. 2016;16(10):1102-1103. doi:10.1016/s1473-3099(16)30329-2.

66. Wardyn SE, Stegger M, Price LB, Smith TC. Whole-Genome Analysis of Recurrent Staphylococcus aureus t571/ST398 Infection in Farmer, Iowa, USA. Emerg Infect Dis. 2018;24(1):153-154. doi:10.3201/eid2401.161184.

67. Webb HE, Angulo FJ, Granier SA, Scott HM, Loneragan GH. Illustrative examples of probable transfer of resistance determinants from food animals to humans: Streptothricins, glycopeptides, and colistin. F1000Research. 2017;6(0):1805. doi:10.12688/f1000research.12777.1.

68. Woolhouse MEJ, Ward MJ. Sources of Antimicrobial Resistance. Science (80- ). 2013;341(6153):1460 LP - 1461. http://science.sciencemag.org/content/341/6153/1460.abstract.

69. World Health Organization (WHO). Antimicrobial Resistance: Global Report on Surveillance. Geneva; 2014. http://apps.who.int/iris/bitstream/handle/10665/112642/9789241564748_eng.pdf;jsessionid=C08C 60691635B5D4635DB3D050DB403C?sequence $=1$. Accessed August 16, 2018.

70. World Health Organization (WHO). Global Antimicrobial Resistance Surveillance System (GLASS) Report: Early Implementation.; 2019.

71. World Health Organization (WHO). WHO GUIDELINES ON USE OF MEDICALLY IMPORTANT ANTIMICROBIALS IN FOOD-PRODUCING ANIMALS. https://apps.who.int/iris/bitstream/handle/10665/258970/9789241550130-eng.pdf?sequence=1. Accessed May 7, 2019.

72. World Organisation for Animal Health (OIE). Global Action to Alleviate the Threat of Antimicrobial Resistance: Progress and Opportunities for Future Activities under the "One Health” Initiative CONSIDERING.; 2017. http://www.oie.int/fileadmin/Home/eng/Our_scientific_expertise/docs/pdf/AMR/A_AMR_RESO_ 2017.pdf. Accessed May 27, 2019.

73. Wozniak TM, Barnsbee L, Lee XJ, Pacella RE. Using the best available data to estimate the cost of antimicrobial resistance: A systematic review. Antimicrob Resist Infect Control. 2019;8(1):1-12. doi:10.1186/s13756-019-0472-z.

74. Zhang Q-Q, Ying G-G, Pan C-G, Liu Y-S, Zhao J-L. Comprehensive Evaluation of Antibiotics Emission and Fate in the River Basins of China: Source Analysis, Multimedia Modeling, and Linkage to Bacterial Resistance. Environ Sci Technol. 2015;49(11):6772-6782. doi:10.1021/acs.est.5b00729. 


\section{Supplemental Material}

\section{Contents}

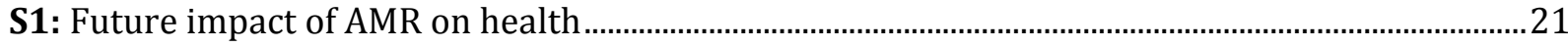

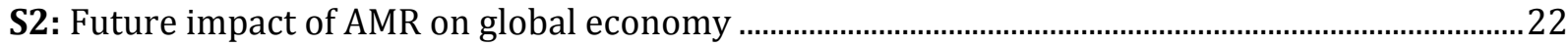

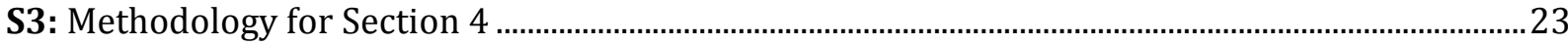

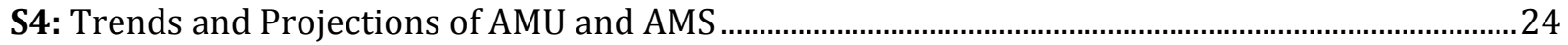

S5: Judicious-use Policies and Regulations in the USA - An Example......................................................26

S Table 1. Summary of current and projected health and economic impacts of antimicrobial

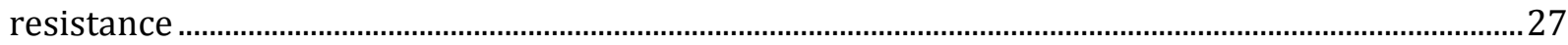

S Table 2. Total amounts of antimicrobial agents used in livestock sector based on electronically available country reports 


\section{S1: Future impact of AMR on health}

Several major reports were compiled that attempt to model the future impacts of AMR, based on projected trends of AMR and infection rates to 2050. These reports include The UK Review on AMR(41) - which utilized analyses commissioned by KPMG and RAND to produce global estimates - and a report commissioned by the Organization for Economic Co-operation and Development (OECD) - which produced estimates for 33 countries in North America, Europe, and Australia. Estimates on the total worldwide deaths attributable to AMR infections ranged greatly, from an average of 60,000 deaths/year in OECD countries to 700,000 deaths/year worldwide. $(34,41,43,58)$ Under multiple scenarios, premature deaths ranged from a cumulative 11 million to 700 million, attributable to AMR by 2050.(34, 58) The AMR Review reported that, unchecked, AMR would result in 10 million deaths per year globally in 2050, and amount to 300 million premature deaths cumulatively by 2050 . $(34,41)$ The OECD model estimated that by 2050, AMR will have caused a cumulative 2.4 million deaths worldwide among OECD countries. The OECD report additionally projected that by 2050, 1.75 million disability-adjusted-life-years (DALYs) will be lost annually due to AMR, across all modelled countries (EU/EEA, U.S., Canada, Australia).(43) In absolute terms, the OECD model estimated that the USA would experience the highest health burden of AMR among OECD countries, with approximately 1 million deaths attributable to AMR infections and an average of 724,000 DALY's lost per year in the USA, by 2050.(43) 


\section{S2: Future impact of AMR on global economy}

The KPMG, RAND, and World Bank reports provide the most recent estimates on the current and projected global economic impact of AMR from a societal perspective (Table 1).(34, 58, 60) Estimates on the indirect economic impact of AMR ranged from $0.06 \%$ to $6.08 \%$ reduced global Gross Domestic Product (GDP), in the RAND and KPMG models respectively, by 2050.(34, 58) The AMR Review, which incorporates both of these analyses, estimated that unchecked, AMR will result in a reduction of the worlds GDP between $2 \%$ and $3.5 \%$ by 2050 , corresponding to a cumulative loss of 60 100 trillion USD worth of economic output.(41) For the analytical methods, assumptions, and limitations of these estimates, we refer readers to the publicly available RAND and KPMG reports. $(34,58)$ The World Bank estimated a 1.1-3.8\% loss in global GDP, corresponding to a loss of \$2-\$6.1 trillion USD annually, by 2050, due to AMR.(60) Similar to The AMR Review, the World Bank reports that the economic burden of AMR is not distributed equally at different levels of economic status, and that the negative impacts are more pronounced in low-income countries than in high-income countries. The World Bank report also noted that AMR in animals would result from declining livestock production due to greater prevalence of untreated disease, which would also be more pronounced in low-income countries.

The OECD and World Bank reports provide the most recent estimates on the projected global economic impact of AMR from a healthcare perspective (Table 1).(43,60) Estimates on the global direct economic impact of AMR ranged from an average of $\$ 3.5$ billion/year among OECD countries to $\$ 1.2$ trillion USD/year worldwide, in the OECD and World Bank reports respectively, by 2050, due to healthcare related costs of AMR. $(43,60)$ In absolute terms the USA is projected to experience the greatest annual healthcare related expenditures as a result of AMR.(43) The OECD report does not provide any estimates on indirect societal costs. We do not attempt to make any inter-estimate comparisons on the current and projected global economic impacts of AMR, for the reasons previously stated. 


\section{S3: Methodology for Section 4}

Country-, regional-, and international reports, along with the scientific literature, were thoroughly researched and scrutinized to collect the total aggregated and individual antimicrobial class sales data within the animal agriculture sector. Both total antimicrobials sold and individual antimicrobial class amounts sold to the animal agriculture sector industry among country-level documents found online were tabulated and provided in Table 4a. For reports and manuscripts where antimicrobial class amounts (either through direct measurement or modeled) were unreported, aggregated values were included to offer the most comprehensive values currently available. (Table $4 \mathrm{~b}$ ) Although we compare data from different years - which as a result may misrepresent the relative intensity of AMS among countries - our objective is to represent the most recent data with the greatest accuracy.

Unfortunately, many countries (primarily low- and middle-income countries) were not found to have publicly reported AMS for animal agriculture use. Therefore, global attribution and economic analyses cannot and should not be based only on data included in this review. Countries that officially reported sales were the same countries that compiled and published consumption data found in the literature.(11) (S Table 2) The region with the largest number country-level responses was Europe - 30 countries reported sales data in a comprehensive European document.(17) (S Tables 2,3) In the Americas, only Canada and the USA were found to have publicly-available reports that described and enumerated AMS data for animal intentions; and in Asia only Japan, Korea, and Australia were identified to report similar data. $(1,8,12,39,49)$ We did not find scientific literature, country, or regional reports that enumerated or described AMS data from African or South American countries. Among international organizations, the OIE report offered total AMS from the same country-reports, which validated our findings.(45) Country- and regional-level documents reported both aggregated data that included total AMS in kilograms (S Table 2), and total amounts of AMS by class in kilograms, although unstandardized across countries. (S Table 2) Some countries reported antimicrobial class totals (e.g. beta-lactams, 3rd generation cephalosporins, etc), while others documented AMS within class (penicillin, amoxicillin, ceftiofur, etc). One resource was found within the scientific literature that modeled global antimicrobial use using currently available sales data. Considering that in 2018, China produced $47.8 \%$ of pork, $11.8 \%$ of poultry, and $10.3 \%$ of beef in the global community, we would be remiss to ignore the country's contribution to antimicrobial use.(62) While national level data is not publicly available, prior publications report estimates of antibiotic consumption in China for food-animal production, delineated in the main text. 


\section{S4: Trends and Projections of AMU and AMS}

In the main text, we describe the most recent data available from reports, documents, and summaries, which elucidates a snapshot of antimicrobials sold mainly to the animal agriculture industry (language utilized by the European Medicines Agency). The US, EU, Canada, and Republic of Korea reports have aggregated sales data which incorporates both food-producing and non-food producing animals. For this analysis, we erred on the side of including all antimicrobial sales, with the assumption that the vast majority of antimicrobials sold to animals are within the livestock sector. This assumption was seen to be valid in comparison to total AMS in Australia, one of the two countries that that do disaggregate food- and non-food producing animals. In Australia, only 17,910 kg of the total 305,910 kg antimicrobials were sold to non-producing animals (5.63\%).(1)

The authors also recognize the importance of historical context to understand trends. Our objective is to describe trends to project and anticipate future estimates of antimicrobials sold to the animal agriculture industry. To accomplish this, this section is divided into three parts. The first two summarize recent trends in AMS in the US and in European countries. The third part reports projected increases in AMU from 2010 to 2030 stratified by region and food-producing animals.

In the USA, the aggregated amount of MIA AMS to animal agriculture dropped by $33 \%$ from $2016(8,356,340 \mathrm{~kg})$ to $2017(5,559,212 \mathrm{~kg})$. Tetracyclines, the most used antibiotic in animal industry, dropped 40\% between 2016 and 2017. Between 2009 to 2017, antibiotic sales to animal agriculture have decreased by an overall $33 \%$. In terms of the type of antimicrobial prescriptions, most prescriptions require VFD for administration of antimicrobials via enriched feed. Between 2016 and 2017, there was a $1,671 \%$ increase in VFD/prescription (from 295,309 $\mathrm{kg}$ to $5,230,663 \mathrm{~kg}$ ). This vast increase is consequential of the precipitous drop (96\%) between 2016-2017 in MIA OTC drugs, which may have been used for production indications. In regard to sales to animal sectors, the cattle industry was sold $2,333,839 \mathrm{~kg}$ ( $42 \%$ of all antimicrobials sold), the swine industry was sold 2,022,932 $\mathrm{kg}(36 \%)$, and the chicken and turkey industry was sold $938,878 \mathrm{~kg}(17 \%)$ of antibiotics. All three industries have seen an overall decrease in consumption of $35 \%, 35 \%$, and $15 \%$, respectively.(12)

European figures collected by the EMA indicated similar decreases in AMS. In 21/30 (70\%) of the European countries, there were decreased AMS between 2015 and 2016. Overall tonnage decreased by $6.6 \%$ ( 8333.90 tonnes to 7787.07 tonnes). Of the 17 countries that participated from 2010 to 2016 (when the EMA began to report EU member state AMS data) - a 32\% decrease in overall AMS (4467.52 tonnes to 3,039.9 tonnes). Tetracyclines and penicillins were the most sold antibiotics classes within animal agriculture. 2012 demonstrates peak sales of tetracyclines was; overall, a drop of $18 \%$ in tetracycline sales was noted from 2010 to 2016. All AMA drug class with the exception of aminoglycosides, which rose, and amphenicols $1^{\text {st- }}$ and $2^{\text {nd }}$-generation cephalosporins, which was essentially unchanged, dropped in sales between 2015 and 2016 on a mg per population correction unit (mg/PCU) basis. Similarly, all classes decreased in mg/PCU between 2011 and 2016 with the exception of amphenicols, cephalosporins, fluoroquinolones, and aminoglycosides. Stratification of sales by species was launched in July 2018 and no data is yet released to determine this metric.(17)

Finally, Van Boeckel et al. predicted global antimicrobial consumption trends needed to produce animal protein from available 2010 data to the year 2030. They employed Bayesian regressions to predict total usage globally and by region and stratified by major food animal species. Van Boeckel et al. 
reported total global antimicrobial consumption within the food sector in 2010 of 63,151 tons, which they modeled to increase to 105,596 tons ( $67 \%$ increase) by 2030 , with $49 \%$ of total consumption attributed to the Asian market (51,851 tons). In 2010, the top five countries who consumed the most antimicrobials were China (23\%), the United States (13\%), Brazil (9\%), India (3\%), and Germany (3\%). Van Boeckel et al. predicted that by 2030 , those contributions will be by China (30\%), the United States (10\%), Brazil (8\%), India (4\%), and Mexico (2\%). Based upon current global eating patterns and trends, by the year 2030 , chicken and pork sectors will increase antimicrobial consumption by $129 \%$ and $124 \%$ respectively.(2) 


\section{S5: Judicious-Use Policies and Regulations in the US - An Example}

For decades, the FDA has promulgated regulations and policies designed to curb uses of antimicrobials within the animal agriculture sector that may contribute to AMR in humans and/or animals and are less critical to maintain animal health. This material will describe the recent history and current regulatory environment in the US as an example of the complexities of AMU regulations in the animal agriculture sector. In 1996, the US established the National Antimicrobial Resistance Monitoring System (NARMS). In its original mandate, NARMS worked with CDC to collect foodborne illness data from humans across 14 states. In 1997, USDA joined the NARMS umbrella to collect animal carcass and fecal samples; and in 2002, the FDA began to sample retail poultry, pork, and beef.(38) NARMS' efforts were fortified by the President's Food Safety Initiative (FSI), released in 1997, which strengthened surveillance and coordinated activities among federal agencies to reduce foodborne illnesses country-wide.(56)

Although NARMS and FSI were not strictly regulatory, they increased awareness of foodborne illness and set the stage for four regulations: GFI \#152, GFI \#209, GFI \#213, and the VFD amendments. FDA's GFI \#152, 209, and 213 documents were not legally binding guidelines, and thus required voluntary adoption by stakeholders. The first of these documents, GFI \#152, was proposed in 1998 as the "Framework Document" and implemented in 2003. It urged the implementation of qualitative risk assessment to determine the potential for animal antimicrobial agents to promote AMR.(7, 19) GFI \#152 also conceptually divided antimicrobial agents into three ordinal categories based on their potency and utility in human medicine. GFI \#209, finalized in 2012, built on the ideas presented in GFI \#152 and was foundational to construct "judicious use of antimicrobials" policies within the animal agriculture sector. GFI \#209 contains non-binding recommendations to advance two major guiding principles. First, the MIA agents listed in GFI \#152 should only be administered "judiciously" to "assure animal health" and thus prohibited for use in feed efficiency and growth promotion. And second, GFI \#209 proposed that MIA should be subject to veterinary oversight to ensure appropriate use.(28) In December 2013, FDA promulgated GFI \#213, which elaborated on the types of antimicrobial access for use in animal agriculture: over-the-counter (OTC), prescription (Rx), and VFD drugs. Notably, GFI \#213 recommended that animal pharmaceutical companies remove production uses from antimicrobial drug labels. In its text, GFI \#213 urged animal drug companies to transition OTC drugs without production labels to either Rx or VFD status. All major animal pharmaceutical companies espoused GFI \#213.(22) Lastly, the VFD amendment, effective in October 2015, legally required veterinary prescription to order antimicrobials labeled for administration in feed, which accomplishes the second guiding principle set forth in GFI \#209.(21) 
S Table 1. Summary of current and projected health and economic impacts of antimicrobial resistance

\begin{tabular}{|c|c|c|c|c|c|c|}
\hline Study & AMR-pathogens & Site of infection & Region & Year & Health burden & Economic burden \\
\hline \multicolumn{7}{|c|}{ Global- and regional- level estimates } \\
\hline $\begin{array}{l}\text { The AMR } \\
\text { Review(41) }\end{array}$ & $\begin{array}{l}\text { MRSA, 3GCR-E. coli, } \\
\text { 3GCR-K. pneumoniae, } \\
\text { Resistant HIV, } \\
\text { Resistant malaria, } \\
\text { MDR-TB }\end{array}$ & $\begin{array}{l}\text { BSI, UTI, Lower RTI, } \\
\text { SSTI }\end{array}$ & Global & $\begin{array}{l}2015- \\
2050\end{array}$ & $\begin{array}{l}\text { Excess deaths attributable to } \\
\text { AMR by 2050: } \\
10 \text { million deaths per year, } \\
\text { resulting in a cumulative } 300 \\
\text { million premature deaths }\end{array}$ & $\begin{array}{l}\text { Societal perspective } \\
\text { Impact on GDP by } 2050 \text { : } \\
2-3.5 \% \text { decrease in global } \\
\text { GDP, depending on scenario } \\
\text { Cumulative worldwide loss: } \\
\text { \$60 trillion - \$100 trillion } \\
\text { USD }\end{array}$ \\
\hline $\begin{array}{l}\text { RAND } \\
\text { Europe(58) }\end{array}$ & $\begin{array}{l}\text { MRSA, 3GCR-E. coli, } \\
\text { 3GCR-K. pneumoniae, } \\
\text { Resistant HIV, } \\
\text { Resistant malaria, } \\
\text { MDR-TB }\end{array}$ & $\begin{array}{l}\text { BSI, UTI, Lower RTI, } \\
\text { SSTI }\end{array}$ & $\begin{array}{l}\text { Global, } \\
\text { including } \\
\text { OECD, EU, } \\
\text { EEA, Latin } \\
\text { America, } \\
\text { Middle East } \\
\text { and North } \\
\text { Africa, } \\
\text { Eurasia, and } \\
\text { Sub-Saharan } \\
\text { Africa }\end{array}$ & $\begin{array}{l}2010- \\
2050\end{array}$ & $\begin{array}{l}\text { Excess death attributable to } \\
\text { AMR by 2050: } \\
\text { 11-444 million reduction in } \\
\text { world population, depending on } \\
\text { scenario }\end{array}$ & $\begin{array}{l}\text { Societal perspective } \\
\text { Impact on GDP by } 2050 \text { : } \\
0.06-3.1 \% \text { decrease in global } \\
\text { GDP, depending on scenario } \\
\text { Cumulative worldwide loss by } \\
\text { 2050: } \\
\text { \$2.1 trillion - } \$ 124.5 \text { trillion } \\
\text { USD }\end{array}$ \\
\hline KPMG(34) & $\begin{array}{l}\text { MRSA, 3GCR-E. coli, } \\
\text { 3GCR-K. pneumoniae, } \\
\text { Resistant HIV, } \\
\text { Resistant malaria, } \\
\text { MDR-TB }\end{array}$ & $\begin{array}{l}\text { BSI, Lower RTI, } \\
\text { SSTI, UTI }\end{array}$ & $\begin{array}{l}\text { Global, } 156 \\
\text { countries }\end{array}$ & $\begin{array}{l}2012- \\
2050\end{array}$ & $\begin{array}{l}\text { Excess death attributable to } \\
\text { AMR by 2050: } \\
\text { 200-700 million reduction in } \\
\text { world population, depending on } \\
\text { scenario }\end{array}$ & $\begin{array}{l}\text { Societal perspective } \\
\text { Impact on GDP by } 2050 \text { : } \\
1.66-6.08 \% \text { decrease in global } \\
\text { GDP, depending on scenario } \\
\text { Cumulative worldwide loss by } \\
\text { 2050: } \\
\$ 14.2 \text { trillion USD under } \\
\text { worst case scenario }\end{array}$ \\
\hline $\begin{array}{l}\text { World } \\
\operatorname{Bank}(60)\end{array}$ & $\begin{array}{l}\text { MRSA, 3GCR-E. coli, } \\
\text { 3GCR-K. pneumoniae, } \\
\text { Resistant HIV, } \\
\text { Resistant malaria, } \\
\text { MDR-TB }\end{array}$ & $\begin{array}{l}\text { BSI, Lower RTI, } \\
\text { SSTI, UTI }\end{array}$ & $\begin{array}{l}\text { Global, } \\
\text { including } \\
\text { OECD, EU, } \\
\text { EEA, Latin } \\
\text { America, } \\
\text { Middle East } \\
\text { and North } \\
\text { Africa, }\end{array}$ & $\begin{array}{l}2017- \\
2050\end{array}$ & NA & $\begin{array}{l}\text { Societal perspective } \\
\text { Impact on GDP by } 2050 \text { : } \\
1.1-3.8 \% \text { decrease in global } \\
\text { GDP, depending on } \\
\text { simulation } \\
\text { Cumulative worldwide loss by } \\
\text { 2050: }\end{array}$ \\
\hline
\end{tabular}




\begin{tabular}{|c|c|c|c|c|c|c|}
\hline & & & $\begin{array}{l}\text { Eurasia, and } \\
\text { Sub-Saharan } \\
\text { Africa }\end{array}$ & & & $\begin{array}{l}\begin{array}{l}\$ 2 \text { trillion - } \$ 6.1 \text { trillion USD, } \\
\text { depending on simulation }\end{array} \\
\text { Healthcare perspective } \\
\text { Impact on healthcare costs } \\
\text { by 2050: } \\
0.33 \text { trillion- } \$ 1.2 \text { trillion } \\
\text { USD, depending on } \\
\text { simulation }\end{array}$ \\
\hline $\operatorname{OECD}(43)$ & $\begin{array}{l}8 \text { bacteria and a total of } \\
17 \text { AMR-bacteria } \\
\text { combinations } \\
\text { Bacteria included: } \\
\text { Acinetobacter spp. } \\
\text { S. pneumoniae } \\
\text { S. aureus } \\
\text { E. coli } \\
\text { K. pneumoniae } \\
\text { P. aeruginosa } \\
\text { Enterococcus faecalis } \\
\text { Enterococcus faecium }\end{array}$ & $\begin{array}{l}\text { Five body sites } \\
\text { including: } \\
\text { BSI } \\
\text { UTI } \\
\text { SSI }\end{array}$ & $\begin{array}{l}\text { EU/EEA } \\
\text { countries, } \\
\text { USA, } \\
\text { Canada, } \\
\text { Australia }\end{array}$ & $\begin{array}{l}2015- \\
2050\end{array}$ & $\begin{array}{l}\text { Excess death attributable to } \\
\text { AMR (current): } \\
60,000 \text { deaths per year } \\
\\
\text { Excess death attributable to } \\
\text { AMR by 2050: } \\
2.4 \text { million deaths per year } \\
1.75 \text { million DALYs lost per } \\
\text { year }\end{array}$ & $\begin{array}{l}\text { Healthcare perspective } \\
\text { Cumulative worldwide loss by } \\
2050 \text { : } \\
\$ 3.5 \text { billion USD per year, } \\
\text { resulting in a cumulative } \$ 134 \\
\text { billion USD } \\
\text { Loss by } 2050 \text { (EU/EEA } \\
\text { countries only): } \\
\$ 1.5 \text { billion USD per year, } \\
\text { resulting in a cumulative } \$ 60 \\
\text { billion USD }\end{array}$ \\
\hline $\begin{array}{l}\text { Temkin et } \\
\text { al., } \\
2019(59)\end{array}$ & $\begin{array}{l}\text { 3GCR-E. coli } \\
\text { CarR-E. coli } \\
\text { 3GCR-K. pneumonia } \\
\text { CarR-K. pneumonia }\end{array}$ & $\begin{array}{l}\text { Serious infections, } \\
\text { BSI }\end{array}$ & $\begin{array}{l}193 \text { member } \\
\text { states of the } \\
\text { United } \\
\text { Nations }\end{array}$ & 2014 & $\begin{array}{l}\text { Cases of serious infection with } \\
\text { 3GCR-Ec and 3GCR-Kp: } \\
50.1 \text { million (27.5-72.8; additive } \\
\text { model) } \\
28.9 \text { million (15.8-41.9; 75\% } \\
\text { replacement model) } \\
\text { Cases of BSI with 3GCR-Ec and } \\
\text { 3GCR-Kp: } \\
6.4 \text { million (3.5-9.2; additive } \\
\text { model) } \\
3.7 \text { million (2.0-5.3; 75\% } \\
\text { replacement model) } \\
\\
\text { Cases of serious infection with } \\
\text { CarR-Ec and CarR-Kp: } \\
\text { 3.1 million (1.8-4.5; additive } \\
\text { model) }\end{array}$ & NA \\
\hline
\end{tabular}




\begin{tabular}{|c|c|c|c|c|c|c|}
\hline & & & & & $\begin{array}{l}2.7 \text { million }(1.5-3.8 ; 75 \% \\
\text { replacement model) } \\
\text { Cases of BSI with CarR-Ec and } \\
\text { CarR-Kp: } \\
0.5 \text { million }(0.3-0.7 ; \text { additive } \\
\text { model) } \\
0.4 \text { million }(0.2-0.6 ; 75 \% \\
\text { replacement model })\end{array}$ & \\
\hline \multicolumn{7}{|c|}{ Country-level estimates } \\
\hline $\begin{array}{l}\text { Cassini et } \\
\text { al., 2019(6) }\end{array}$ & $\begin{array}{l}\text { CR-A } \\
\text { CarR-A } \\
\text { MDR-A } \\
\text { VR-E. faecalis } \\
\text { VR-E. faecium } \\
\text { CR-Kp } \\
\text { CarR-Kp } \\
\text { 3GCR-Kp } \\
\text { CR-Pa } \\
\text { CarR-Pa } \\
\text { MDR-Pa } \\
\text { MRSA } \\
\text { PR-Sp } \\
\text { MR-Sp }\end{array}$ & $\begin{array}{l}\text { BSI, UTI, RTI, SSI, } \\
\text { Other infections, } \\
\text { Secondary BSI }\end{array}$ & $\begin{array}{l}\text { Member } \\
\text { states of the } \\
\text { European } \\
\text { Union and } \\
\text { European } \\
\text { Economic } \\
\text { Area }\end{array}$ & 2015 & $\begin{array}{l}\text { Cases of infection: } \\
671,689 \text { ( } 95 \% \text { UI: } 583,148- \\
763,966) \\
\text { Attributable mortality: } \\
33,110(28,480-38,430) \\
\text { DALYs: } \\
874,541 \text { (768,837-989,068) } \\
\\
\text { Incidence: } \\
131 \text { (113-149) infections per } \\
100,000 \\
\text { Incidence of attributable } \\
\text { mortality: } \\
\text { 6.44 (5.54-7.48) deaths per } \\
\text { 100,000 population } \\
\text { Incidence of DALYs: } \\
\text { 170 (150-192) DALYs per } \\
\text { 100,000 population }\end{array}$ & NA \\
\hline $\begin{array}{l}\text { Thorpe et } \\
\text { al., } \\
2018(51)\end{array}$ & $\begin{array}{l}\text { Pathogens in CDC } \\
\text { report (2013)(61) } \\
\\
\text { Clinically validated list } \\
\text { of bacterial infections } \\
\text { from Schneeweiss et } \\
\text { al., 2007(27) }\end{array}$ & $\begin{array}{l}\text { Complicated intra- } \\
\text { abdominal infection } \\
\text { Bacteremia/sepsis } \\
\text { Cellulitis } \\
\text { Encephalitis } \\
\text { Intestinal infection } \\
\text { Osteomyelitis/septic } \\
\text { arthritis } \\
\text { Pneumonia } \\
\text { UTI } \\
\text { Unspecified bacterial } \\
\text { infection }\end{array}$ & USA & $\begin{array}{l}2002- \\
2014\end{array}$ & $\begin{array}{l}\text { Total cases of AMR infections: } \\
1.2 \text { million infections per year } \\
\text { (average, 2002-2014) } \\
1.6 \text { million infections per year } \\
(2014)\end{array}$ & $\begin{array}{l}\text { Payer perspective: } \\
\text { Average incremental } \\
\text { healthcare cost per case: } \\
1,383.15 \text { USD (SD = 170.08) } \\
\text { Average national } \\
\text { expenditure: } \\
2.2 \text { billion USD per year }\end{array}$ \\
\hline
\end{tabular}




\begin{tabular}{|c|c|c|c|c|c|c|}
\hline $\begin{array}{l}\text { CDC } \\
\text { Report } \\
(2013)(27)\end{array}$ & $\begin{array}{l}\text { CarR-E } \\
\text { MDR-A } \\
\text { FR-C } \\
\text { ESBL+E } \\
\text { VR-Enterococcus } \\
\text { MDR-Pa } \\
\text { DR-Ng } \\
\text { DR-C } \\
\text { DR-NTS } \\
\text { DR-ST } \\
\text { DR-Shigella } \\
\text { MRSA } \\
\text { VRSA } \\
\text { DR-Sp } \\
\text { ER-GAS } \\
\text { CR-GBS }\end{array}$ & Various & USA & 2011 & $\begin{array}{l}\text { Estimated minimum number of } \\
\text { illnesses due to AMR-infections: } \\
2,049,442 \\
\text { Estimated deaths due to AMR- } \\
\text { infections: } \\
23,000\end{array}$ & $\begin{array}{l}\text { Healthcare perspective } \\
\text { Excess direct healthcare } \\
\text { costs: } \\
\text { \$20 billion USD annually } \\
\text { Societal perspective } \\
\text { Excess societal costs: } \\
\text { \$35 billion USD annually }\end{array}$ \\
\hline $\begin{array}{l}\text { Shrestha et } \\
\text { al., } \\
2018(53)\end{array}$ & $\begin{array}{l}\text { MRSA } \\
\text { 3GCR-E. coli } \\
\text { 3GCR-K. pneumonia } \\
\text { CarR-A. baumanii } \\
\text { CarR-P. aeruginosa }\end{array}$ & $\begin{array}{l}\text { BSI } \\
\text { UTI } \\
\text { RTI } \\
\text { SSI } \\
\text { SSTI } \\
\text { Endocarditis } \\
\text { Pneumonia } \\
\text { Bone and joint } \\
\text { infection (BJI) } \\
\text { Other infections }\end{array}$ & $\begin{array}{l}\text { USA } \\
\text { Thailand }\end{array}$ & $\begin{array}{l}\text { USA: } \\
2011 \\
\\
\text { Thailand: } \\
2010\end{array}$ & $\begin{array}{l}\text { Total infections } \\
\text { USA: } 129,761 \\
\text { Thailand: } 87,751 \\
\text { Excess deaths attributable to } \\
\text { AMR } \\
\text { USA: } 14,535 \\
\text { Thailand: } 19,122\end{array}$ & $\begin{array}{l}\text { Healthcare perspective } \\
\text { Direct healthcare cost due to } \\
\text { human antibiotic } \\
\text { consumption: } \\
\text { USA: } \$ 68 \text { million USD } \\
\text { Thailand: } \$ 52 \text { million USD } \\
\text { Societal perspective } \\
\text { Indirect societal cost due to } \\
\text { human antibiotic } \\
\text { consumption: } \\
\text { USA: } \$ 2.81 \text { billion USD } \\
\text { Thailand: } \$ .44 \text { billion USD } \\
\text { Total economic cost (direct } \\
\text { + indirect) } \\
\text { USA: } \$ 2.9 \text { billion USD } \\
\text { Thailand: } \$ 0.5 \text { billion USD } \\
\text { Externality } \\
\text { Cost of AMR per SU of } \\
\text { antibiotic consumed: } \\
\text { USA: } \$ 0.1 \text { USD per SU for } \\
\text { carbapenems - \$0.6 USD per }\end{array}$ \\
\hline
\end{tabular}




\begin{tabular}{|c|c|c|c|c|c|c|}
\hline & & & & & & $\begin{array}{l}\text { SU for quinolones, } \\
\text { cephalosporins and broad } \\
\text { spectrum penicillins } \\
\text { Thailand: } \$ 0.1 \text { USD per SU } \\
\text { for macrolides - } \$ 0.7 \text { USD per } \\
\text { SU for quinolones, } \\
\text { cephalosporins and broad } \\
\text { spectrum penicillins }\end{array}$ \\
\hline \multicolumn{7}{|c|}{ Meta-analysis of AMR-pathogen specific estimates } \\
\hline $\begin{array}{l}\text { Wozniak et } \\
\text { al., } \\
2018(73)\end{array}$ & $\begin{array}{l}\text { A review of } 14 \\
\text { studies/reports which } \\
\text { concludes high quality } \\
\text { estimates for: MRSA, } \\
\text { 3GCR-E, ESBLP-E }\end{array}$ & BSI & Various & $\begin{array}{l}2012- \\
2016\end{array}$ & NA & $\begin{array}{l}\text { Healthcare perspective } \\
\text { LOS: } \\
\text { MRSA: }+2.54 \text { days (-3.19- } \\
\text { 8.27) (Stewardson 2016) } \\
\text { 3GCR-E: }+4.89 \text { days }(1.11- \\
\text { 8.68) (Stewardson, 2016) } \\
\text { ESBLR-E: }+6.8 \text { days } \\
\text { (Stewardson 2013) } \\
\\
\text { Excess healthcare cost: } \\
\text { MRSA: } € 1600 \text { EUR } \\
\text { 3GCR-E: } € 3200 \text { EUR } \\
\text { ESBLR-E: } 9473 \text { CHF }\end{array}$ \\
\hline
\end{tabular}




\section{$S$ Table 2. Total amounts of antimicrobial agents applicable mainly for food-producing animals based on electronically available country reports.}

\begin{tabular}{|c|c|c|c|c|c|c|c|}
\hline & \multirow{2}{*}{$\begin{array}{c}\text { Class of } \\
\text { Antimicrobials }\end{array}$} & \multicolumn{6}{|c|}{ Amount of active antimicrobial ingredients used by country/region (kg) } \\
\hline & & US (2017) & EU (2016) & AUS $(2010)^{a}$ & CAN (2016) & $\operatorname{JAP}(2015)^{\mathrm{a}}$ & ROK (2012) \\
\hline \multirow{14}{*}{ 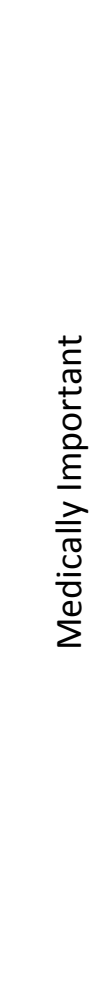 } & Aminoglycosides & 232,504 & 399,300 & 5,880 & 14,952 & 35,467 & 46,071 \\
\hline & Amphenicols & 49,321 & 99,700 & 900 & - & 29,728 & 83,423 \\
\hline & Cephalosporins $^{b}$ & 29,369 & 19,700 & 3,300 & 6,766 & 5,895 & 7,759 \\
\hline & Quinolones $^{c}$ & 22,904 & 198,800 & 280 & 378 & 9057 & 49,149 \\
\hline & Lincosamides & 152,497 & 237,500 & 6,480 & 48,083 & 28,660 & 9,172 \\
\hline & Macrolides & 468,794 & 546,600 & $10.7^{d}$ & 97,453 & 98,408 & 55,924 \\
\hline & Penicillins & 690,889 & $2,009,800$ & 31,830 & 133,722 & 94,725 & 189,748 \\
\hline & Polymyxins & - & 397,200 & - & - & - & - \\
\hline & Pleuromutilins ${ }^{e}$ & - & 218,300 & - & - & - & 17,740 \\
\hline & Sulfas & 274,112 & 897,900 & 20,030 & - & 96,670 & 102,273 \\
\hline & Tetracyclines & $3,535,701$ & $2,251,000$ & 59,010 & 513,890 & 333,858 & 281,974 \\
\hline & Trimethoprim & - & 148,300 & - & - & 12,146 & - \\
\hline & $N I R^{f}$ & 76,440 & 93,100 & 171,870 & 187,070 & 49,366 & 44,916 \\
\hline & SUBTOTAL & $5,559,212$ & $7,787,100$ & 299,580 & $1,002,313$ & 756,498 & 888,149 \\
\hline \multirow{4}{*}{ 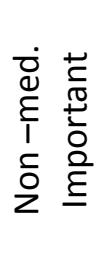 } & Ionophores & $4,394,850$ & - & 11,700 & 487,733 & - & 47,618 \\
\hline & $N I R^{g}$ & 979,306 & - & 12,300 & 85,935 & - & 602 \\
\hline & SUBTOTAL & $5,374,156$ & - & 24,000 & 573,668 & - & 48,220 \\
\hline & GRAND TOTAL & $10,933,367$ & $7,787,200$ & 195,870 & $1,575,982$ & 756,498 & 936,369 \\
\hline
\end{tabular}

a. Australia and Japan reports allow for disaggregation of food and non-food producing animals, whereas the other country-reports may include non-food producing animals in their estimates. For comparison, this includes non-food producing animals.

b. Cephalosporins class include all generations of cephalosporins (i.e. 1st, 2nd, 3rd, and 4th)

c. Quinolones class include both "Fluoroquinolones" and "Other Quinolones"

d. Australia lists macrolides and streptogrammins for therapeutic uses and streptogrammins together, therefore grouped with "NIR". This amount reflects macrolides administered for growth-protant purposes

e. Pleuromutlilins class is listed as WHO "important" to human medicine, although other countries (e.g. United States) considers this drug non-medically important.

f. "Not Independently Reported" includes other antimicrobial classes not listed, "other" categories from country-wide reports, and combination antimicrobial classes reported (e.g. Trimethoprim and Sulfonamides aggregated data: (US: Diaminopyrimidines, Polymyxins, and Streptogramins; EU: 2 Bacitracin, fosfomycin, furaltadone, lincosamides, macrolides metronidazole, novobiocin, paromomycin, polymyxins, pleuromutilins, rifaximin, and spectinomycin; AUS: aminocoumarins, macrolides and streptogrammins, nitroimidazoles, polypeptides, and "others"; CAN: Trimpethroprim, sulfonamides, avilamycin, bacitracins, bambermycin, chloramphenicol, chlorhexidine gluconate, florfenicol, fusidic acid, nitarsone, nitrofurantoin, nitrofurazone, novobiocin, polymixin, tiamulin, and virginiamycin; JAP: furan and derivatives, ormethoprim, tiamulin (derivatives), valnemline, bicozamycin (derivatives), Fosfomycin (derivatives), fosforycin; ROK: novobiocin, polypeptides, streptogrammins, and "others")

g. "Not Independently Reported" includes other non-medically important antimicrobial classes including glycopeptides, polypeptides, quinoxalines, and orthosomycins. However, discrepancies exist between what constitutes medically important, therefore some countries may incorporate antimicrobials into "other" as non-medically important, while WHO considers it to be important. (US: aminocoumarins, glycolipids, orthosomycins, pleuromutilins, Polypeptides, and Quinoxaline; AUS: glycopeptides, oligosaccharides, and quinoxaline; CAN: chemical coccidiostats; ROK: orthomycins, glycopeptides. 